\title{
Climbing the Poverty Ladder:
}

\section{The Role of Entrepreneurship and Gender in Alleviating Poverty}

\author{
in Transition Economies \\ Julia Korosteleva ${ }^{a}$ and Paulina Stępień-Baig ${ }^{b}$ \\ ${ }^{a}$ University College London, UK, j.korosteleva@ucl.ac.uk, corresponding author \\ b University College London, UK, paulina.baig@ gmail.com
}

\begin{abstract}
Poverty reduction remains a critical issue for a vast proportion of the population globally. Substantial body of literature on poverty reduction has focused on the role played by government support and charity institutions, whereas entrepreneurship as a channel for poverty reduction, and the role of gender in shaping this relationship have been under-researched, especially in the context of transition economies. Using the recent wave of the EBRD Life in Transition Survey III (2016) data, this study explores the relationship between poverty alleviation, entrepreneurship and gender. We extend the understanding of the mechanism via which entrepreneurial process is likely to contribute to poverty reduction in this region, distinguishing between self-employment and business ownership, with the latter regarded as Schumpeterian entrepreneurship. The study provides some interesting findings shedding light on the important role women play in shaping the entrepreneurship-poverty relationship.
\end{abstract}

Keywords: Income-poverty ladder, subjective, objective poverty, entrepreneurship, gender, infrastructure, transition economies. 


\section{Introduction}

Poverty is a complex phenomenon spanning multiple economic and social issues (Misturelli and Heffernan, 2008). Poverty reduction remains a critical issue for a vast proportion of the world's population with more than two billion individuals in developing countries along surviving on under US \$3.10 per day (World Bank, 2017). However, the last decade has seen some positive achievements in fighting poverty (Bruton, Ahlstrom, \& Si, 2015; Wu \& Si, 2018; Tomizawa, Zhao, Bassellier, \& Ahlstrom, 2019). Such success has led many academic scholars and policy-makers to continue exploring the instruments which provide efficient solutions for fighting poverty in the context of specific countries, regions and worldwide. Among others, entrepreneurship has been increasingly recognized as one of the efficient means for achieving economic prosperity and poverty reduction.

One of the widely acclaimed channels via which entrepreneurship promotes economic prosperity and reduces poverty has been job creation, leading to the reduction of unemployment via (a) individuals getting engaged in entrepreneurial activity themselves; (b) creating new jobs via establishing high-growth potential businesses (Estrin et al., 2013; Phelps, 2013). Entrepreneurship also increases economy's productivity via the process of creative destruction (Schumpeter, 1934), disrupting markets with introduction of new products and technologies, and challenging the power of incumbent inefficient firms (Phelps, 2013). The overall economic growth benefits resulting from productivity growth accrue not only to the rich but also to the poor given that on average growth is distribution neutral, i.e. it benefits the poor proportionately as much as the rest of the population (Dollar and Kraay, 2013).

A substantial body of literature on poverty reduction has focused on the role played by government support and charity institutions, whereas entrepreneurship as a channel for poverty reduction has been under-researched so far (Bruton et al., 2013; Si et al. 2015). In particular, there is still a lack of quantitative evidence to shed some light on the extent to what entrepreneurship is 
efficient in fighting poverty in the context of emerging economies of Central and Eastern Europe, and Central Asia, known as transition economies.

Furthermore, the debates on poverty have been surrounded by the issue of gender inequality, raising concern that poverty has predominantly a woman's face (Sanchez, 2018). Some evidence suggests that worldwide, women are poorer and more disadvantaged than men due to their limited access to education, lack of ability to exercise property, economic and political rights (Duflo, 2012; Munoz-Boudet, 2018). Economic empowerment of women to widen the opportunities available to them in the labor market is increasingly acclaimed as one of the effective instruments to reduce gender poverty gap (Duflo, 2012). Engaging in entrepreneurial activity may offer women such opportunity to break the circle of poverty.

This paper addresses these issues empirically, exploring the linkages between entrepreneurship, gender and poverty alleviation in the setting of transition economies. Our main contributions can be summarized as follows. First, there is still lack of empirical evidence offering insights on the relationship between entrepreneurship, gender and poverty alleviation, in particular in the setting of emerging economies of Central and Eastern Europe, and Central Asia. To investigate our research questions, we utilize the 2016 EBRD Life in Transition Survey (LiTs) data that covers the countries of interest and therefore also enables a comparative perspective to study cross-country group differences.

Second, we extend the understanding of the mechanism via which entrepreneurial process is likely to contribute to poverty reduction, distinguishing between self-employment and business ownership, with the latter viewed here as the Schumpeterian entrepreneurship (Henrekson and Sananaji, 2014). We also provide some interesting findings shedding light on the important role females play in shaping the entrepreneurship-poverty relationship, revisiting the conventional views on this. 
Third, we employ a sophisticated methodology, utilizing a multilevel modelling technique. It allows to distinguish between individual and multi-level environmental effects. The data contains information on cities where respondents reside, allowing us to construct a regional district-level variable. We build a three-level model to study the determinants of poverty alleviation via looking at individuals, regional districts and country factors in a multilevel framework, the advantage of which is allowing micro-, meso- and macro-levels to be modelled simultaneously, addressing the clustering effect of individuals within districts and countries, failure of doing which may lead to biased results.

The paper proceeds as follows. Section 2 reviews the exsiting academic literature exploring the determinants of poverty alleviation, focusing specifically on the issues of entrepreneurship and gender primarily in the setting of transition. Section 3 discusses data and methodology employed in this study. Sections 4 and 5 discuss the empirical results contextualizing them within the literature, whereas Section 6 concludes, summarizing key findings and providing some policy recommendations and agenda for future research.

\section{Determinants of Poverty Alleviation: Theoretical Literature Overview and Hypotheses}

\section{Development}

The literature on poverty determinants has been growing fast, spanning different fields of stuides, primarily dominated by development economics, but remaining fairly scarce in the field of management (Bruton et al., 2013; Si et al. 2015). Among others, prior studies on poverty reduction emphasize the importance of microcredit schemes (Prahad, 2005; Bruton et al. 2011); literacy (Banerjee et al., 2007); education and skill training (Duflo, 2012); institutional change and entrepreneurship (McMullen, 2010; Khavul et al. 2013).

\subsection{Entrepreneurship and its Role in Poverty Alleviation}


A number of scholars attest to the importance of entrepreneurship in alleviating poverty (McCloskey, 2010; Bruton et al. 2013; Si et a. 2015).

Entrepreneurship is seen as a route out of deprivation; business owners in the most deprived areas are more likely to move than comparable non-business owners to more prosperous areas, and therefore more likely to achieve an improvement in their standard of living (Frankish et al. 2014). Whereas the deprived areas are likely to be populated by low-value adding businesses with little scope to grow due to resource constrains, and respectively lower potential to reduce poverty (Blackburn and Ram, 2006; Greene, 2008).

Prahalad (2005) emphasized the role entrepreneurs may play in serving the needs of the poor, and how serving the bottom of the pyramid may make them prosper in turn. However, it is not only the explotation of market opportunities with the focus on poor that helps alleviating poverty; entrepreneurs coming from impoverished backgrounds can also help to inspire the poor to engage in entrepreneurship seeing it as a route of poverty (Si et al., 2015).

Entrepreneurial dynamism has been argued to be particularly vital for transition economies (Jackson et al., 1999). With the collapse of communism, which was characterized by the suppression of private initiative, since early 1990s transition economies have undergone a colossal change involving comprehensive institutional reforms as they moved towards a market economy with entrepreneurship assuming one of the core roles in affecting all aspects of economic development in the region (Korosteleva and Belitski, 2017).

Despite a number of hardships, including economic instability, institutional deficiencies, lack of public support and hostile social attitudes towards entrepreneurship, de novo firms experienced exponential growth in the early 1990s, driven by abundant market opportunities, which were suppressed under the communist system, and emerging institutional opportunities (Smallbone and Welter, 2001). 
A surge in new venture creation in transition economies throughout the 1990s rendered its outcomes positively affecting economic growth and income distribution across the region. In their study of the relationship between entrepreneurship and the evolution of income distributions in Poland and Russia, Berkowitz and Jackson (2006) show that a one-standard-deviation increase in the share of the workforce in new or small enterprises increases the share of income earned by the lowest forty percent of the population by 1.4 and by 1.25 percentage points in Polish and Russian regions respectively. Poland's greater success in de novo firm entry contributes to its more equitable income distribution during the transition. Poland also stands out illustrating the success of self-employment in tackling poverty. Self-employment was introduced in Poland as a new occupational choice category (outside agriculture) in 1992. In his study of income, inequality and poverty during the transition, Milanovic (1997) shows that being a self-employed reduces the probability of poverty by 11 percent, when controlling for other factors such as education, type and size of household, location and so on. Interestingly, this effect is not uniform across all transition economies with lower than average poverty rates observed for self-employed in Hungary and Poland; about average - in Belarus and Slovak Republic, and higher than average in Estonia and Romania. Such divergences across transition countries are likely to reflect lack of homogeneity in defining self-employment, where a category seems to be too broad spanning both small-scale subsistence farmers and rich private entrepreneurs in some transition economies.

The Chinese economy which has also undergone a significant institutional change towards developing a market economy in the last decades, has witnessed significant poverty reduction, largely attributed to entrepreneurial developments taken place in China (Ahlstrom and Ding, 2014; Si et al. 2015). Based on the case study of the Eastern Chinese city of Yiwu, Si et al. (2015) showed how individual and collective entrepreneurship helped to reduce poverty in the region via not only disrupting the market with products that are affordable to the bottom of the pyramid, but also setting the positive role model examples, motivating the others to follow suit. 
In considering the relationship between entrepreneurship and poverty further, the scholars have also continuously debated about the role of different types of entrepreneurship and its effect on prosperity and poverty reduction, distinguishing between necessity- and opportunity-driven entrepreneurship (Vallierie \& Peterson, 2009), or lower-value adding and high-impact (Schumpeterian) entrepreneurship (Estrin et al. 2013; Henrekson and Sanandaji, 2014). Following Henrekson and Sanandaji (2014), the term "entrepreneur" conflates two broad categories of individuals: (1) individuals who are effectively self-employed, generating jobs primarily for

themselves; (2) Schumpeterian entrepreneurs who aspire to create large scale businesses that could impact the growth path of their local region or even the national economy. We expect the latter to have disproportionally stronger effect on poverty reduction, given its higher growth-impact potential, whereas a self-employment, viewed as less productive activity and driven often by necessity motive in the setting of transition, to have a less pronounced effect on poverty reduction.

Based on this discussion, we postulate our first set of hypotheses.

Hypothesis 1: The engagement of individuals in (a) self-employement (HIa) and (b) business ownership with employment creation $(H 1 b)$ is likely to have respectively positive effect on poverty reduction. The effect of business ownership is expected to be stronger on poverty reduction as opposed to self-employment (H1c).

\subsection{Is Poverty Gender Neutral?}

It has been long established that poverty disproportionately affects women (Sanchez, 2018). All major international organisation such as the UN, the World Bank, European Union in the recent years have undertaken projects aimed at better understanding of poverty among men and women. In most cases, 
within poor households women are engaged in household and childbearing duties while men work for income. This means that women are often poorer and more vulnerable than men.

A recent initiative between United Nations (UN) Women and the World Bank reassessed survey data for 89 countries focusing specifically on poverty gender gap (Munoz-Boudet et. al., 2018). Children account for 44 per cent of the world's extremely poor with girls being disproportionally affected. As the children grow up, the gender gap widens - for every 100 poor men aged 25-34 there are 122 poor women of the same age group. European Institute for Gender Equality (2016) highlighted in their report on the poverty in the EU that women continue being at higher risk of poverty due to inequalities in public and private lives which weaken women's opportunities in the labour market and devalue their work.

Turning to the transition economies, most of the literature on poverty focuses on the early transition period and the effect of the collapse of communism and economic transformation on poverty and inequality (Rosser et al, 2000; Simai, 2006).

The economic and social transformation of post-communist countries was claimed to affect men and women in different ways, creating both challenges and opportunities (Falkingham \& Baschieri, 2010; Sattar, 2011). On the one hand side, with the launch of the economic reforms in early 1990s, it was predicted that impoverishment would predominately take a female face with expected fall in female labour participation, increase of unemployment among women, and a rising gender wage gap (Ashwin, 2010). Some evidence suggests that women indeed were affected by the transition experience disproportionately more than men, with many women being forced into unemployment and poverty (Mickiewicz, 2010). Gender equality promoted during communism, and argued to contribute to sustaining female labour participation during the early start of transition, has also quickly been eroded particularly in countries of Central Asia and the Caucasus (Falkingham \& Baschieri, 2010; Sattar, 2011). For many women in Central Asia the gains in leadership positions and 
political representation achieved during the Soviet times, have been reversed with re-emergence of the traditional gender roles in taking primary care of household chores (Harris, 2004).

However, other studies suggest only marginal gender differences in poverty observed between men and women (Ashwin, 2010). Marginal gender gap could be partly explained via the perseverance of female labour participation rates due to the emergence of new economic opportunities as a result of structural transformation: the contraction of the manufacturing sector with a disproportionate adverse effect on men, and the expansion of the service sector that opened relatively more opportunities for women (Sattari, 2011). However, women's gains in the service sector may be only short term with little scope for growth (Sabbarwal and Terrel, 2008) as discussed further below.

Nevertheless, the World Bank poverty assessments in the region in the first decade of transition even revealed some evidence that female-headed households fared sometimes better than those headed by males; in Kyrgystan in 2003 only 36 per cent of female-headed households were defined as poor, living below USD2.15 PPP a day, as compared to 67 per cent of male-headed households (Alam et al., 2005: 238-41). In her study of Russia's experience of the shock therapy economic reform in the 1990s, Ashwin (2010) reveals continuities in women's attachment to the labour force primarily as a result of economic need and women's responsibility for domestic childcare. Paradoxically, women have proved more resilient than men in facing economic deprivation during the economic reform. If men experience labour market problems with their position as main household 'breadwinners' being challenged, they turn to marginalize themselves even further from their household, immersing into 'binge drinking' which further exacerbate their economic hardships (Jukkala et al., 2008). Women, however, are found less likely to binge drink when experiencing economic problems, and their continuing labour market engagement to support the household at the times of economic hardships helps them to sustain a sense of 'efficacy, competence and meaning' (Jukkala et al., 2008; Ashwin, 2010).

Based on the above two-fold argument, we postulate our second hypothesis. 
Hypothesis 2: Poverty is expected to be higher among females as opposed to males in the context of transition economies, although a poverty gap is not substantial.

Now we turn to considering to what extent gender plays any critical role in explaining the entrepreneurship-poverty relationship. Female entrepreneurship has increasingly become the global phenomenon with businesses owned by women representing between $25 \%$ and $33 \%$ of formal sector business around the world (Minniti et al. 2005; Estrin and Mickiewicz, 2011).

Referring to Global Entrepreneurhsip Monitor data on entrepreneurship (GEM, 2016), we observe some cross-country and cross-regional differences in the role of gender in entrepreneurship. Overall, males dominate entrepreneurial entry and they are more growth ambitious (ibid). In transition economies in 2015 we observe 50 per cent lower entrepreneurial entry for women as compared to men, though women show nearly equal to men opportunity-driven entrepreneurship rates ${ }^{1}$. Macedonia and Slovenia exhibit the lowest female-to-male entrepreneurial entry, equal to 0.4 , whereas in Hungary women show lower opportunity-driven motivation as compared to men (0.7). Overall, after more than 25 years since the beginning of transition, oberving a higher rate of women entering entreprenership out of opportunity motive is a positive trend towards poverty eliminiation, given that such process was largely dominated by a necessity motive during the early stage of transition (Falkingham \& Baschieri, 2010).

As highlighted above, women not only exhibit the overall lower entrepreneurial entry rate as compared to men, but also they show some differences in business performance. While the evidence on gender and its effect on firm performance is mixed (for good overview of this literature see Parker,

\footnotetext{
${ }^{1}$ These figures reflect a group average for transition economies and are calculated based on GEM (2016) report. In the year of survey used for drafting this report, among transition economies there were the following countries that took part in the survey: Bulgaria, Croatia, Estonia, Hungary, Kazakhstan, Latvia, Macedonia, Poland, Romania, Slovak Republic, and Slovenia.
} 
2018), in their majority academic scholars come to consensus that growth and survival rates among female-run businesses are generally smaller compared to males (Sabarwal and Terrel, 2008; Parker, 2018). Using firm-level data from 26 transition economies of Central and Eastern Europe, and Central Asia, Sabarwal and Terrel (2008) find that female entrepreneurs own and manage smaller and less efficient (in terms of total factor productivity) enterprises, although the difference is small. However, female entrepreneurs' returns to scale are much larger suggesting they would benefit most from increasing their scale of operations (ibid). Sabarwal and Terrel (2008) conclude that the main reasons of females operating suboptimal-size businesses are that they are both financially more constrained and tend to concentrate in industries with predominately small firms such as retail sales and services; they are also less likely to operate high-tech businesses. This is also in line with other studies (e.g. Muravyev et al. 2007; Ashwin 2010). In conclusion, all this may have implications for a type of business women are likely to launch, and its further implications for their welfare. If self-employment is likely to reflect more replicative, small-scale business, we expect women to perform less well than man with also having less opportunities compared to men to climb the poverty ladder. On opposite, business ownership with employment creation shows an effort for creating more sizable growthambitious firms. If women launch such enterprises, they are more likely to succeed as compared to men. Based on this we formulate our next set of the hypotheses.

Hypothesis 3: Females engaged in (a) self-employment and (b) business ownership are likely to be respectively lower down $(\mathrm{H} 3 \mathrm{a})$ and higher up $(\mathrm{H} 3 \mathrm{~b})$ the poverty ladder compared to their male counterparts.

\subsection{Regional differences}


In this study we do not only focus on the sample of transition economies as a whole, but also distinguish between different country groups within transition economies. In this we follow the EBRD classification: Central Europe and Baltic States (CCB); South East Europe (SEE); Eastern Europe (EEC); and Central Asia (CA $)^{2}$.

In their study of female entrepreneurship in Lithuania and Ukraine, Aidis et al. (2007) claim that females have less access to finance both formal and informal, less access to informal networks and different attitude to risk. However, they stress that there exist significant differences between the two countries which affect female entrepreneurs and suggest that the transition region should not be viewed as uniform and regional approach considered when studying it.

The differences across these country groups in determining entrepreneurship-gender-poverty relationships are likely to be driven by the institutional environment (McMullen et al. 2010) that may be more conducive to entrepreneurship in Central and Eastern Europe following their accession to the EU, but provides some constraints for new venture creation in Eastern Europe and Central Asia both spanning the countries of the Former Soviet Union (FSU) (Aidis et al., 2008; Manolova et al., 2008; Estrin and Mickieiwicz, 2011). Estrin and Mickiewicz (2011) show that lower rates of entrepreneurial activity in the FSU region as compared to Central European transition economies is attributed to the negative effect of the legacy of communist planning, including the negative attitude of the society to entrepreneurship (Estrin and Mickiewicz, 2011).

Furthermore, the institutional constraints that entrepreneurs face, do not only determine the rate of entrepreneurial activity but also its type (Baumol, 1990; Estrin et al. 2013). In a more deficient institutional environment, we may expect lower level of high-impact entrepreneurship as opposed to self-employment. We expect to observe more incidences of subsistence entrepreneurship among

\footnotetext{
${ }^{2}$ Here is a full list of countries comprising each of these groups: CEB: Croatia, Estonia, Hungary, Latvia, Lithuania, Poland, Slovak Republic, Slovenia. SEE: Albania, Bosnia and Herzegovina, Bulgaria, FYR Macedonia, Kosovo, Montenegro, Romania, Serbia. EEC: Armenia, Azerbaijan, Belarus, Georgia, Moldova, Ukraine. CA: Kazakhstan, Kyrgyz Republic, Tajikistan, Turkmenistan, Uzbekistan, Russia.
} 
females in Central Asia, given the scarcity of alternative labour market opportunities. On the other hand, in CCB states the entrepreneurship is likely to be opportunity-driven. Females are more critical of themselves in their entrepreneurial endeavours. This is likely to lead to the emergence of more successful and therefore wealthier female entrepreneurs (Simai, 2006; Scott et al., 2012).

Finally, another reason for observing regional differences is rooted into cultural differences in the role females play in business in Central Asia as opposed to Central and East European countries (Welter et al., 2003). Since the launch of transition, the Soviet culture on promoting gender quality was diminished with traditional cultural and social values emphasizing a strong gender hierarchy of power relationship with men playing a dominant role in the household and women playing submissive role within the family, taking care of household chores, having revived in the region (Harris, 2004). Furthermore, it is also worth noting that the unitary household assumption with household income being equally shared between men and women, commonly used in assessing poverty (e.g. Alam et al., 2005), is less likely to hold in Asian countries, and therefore actual gender differentials in welfare in this region are likely to be underestimated (Falkingham \& Baschieri, 2010).

Overall, the lower rates of entrepreneurial activity in EEC and CA as compared to the CCB region; the prevalence of its different types (self-employment as opposed to business ownership with employment); the cultural differences underlying the different role women play in business in Central Asia leads to postulating our last set of hypotheses.

Hypothesis 4: Regional differences determine the relationship between entrepreneurship, gender and poverty: a poverty reduction effect of female engaging in any form of entrepreneurship is likely to be observed in the context of CEB countries ( $\mathrm{H} 4 \mathrm{a})$; in Central Asia we are likely to observe a significant gender gap in the effect of different types of entrepreneurship on poverty to a disadvantage of women $(H 4 b)$. 


\section{Data and Methology}

To test our hypotheses we utilize the most recent wave of the EBRD Life in Transition Survey (LiTS) III conducted in $2016^{3}$. It surveys 51,000 households across 34 countries, with the primary focus on transition economies (28 countries).

\subsection{Measuring Poverty}

Poverty is a multifaceted concept underlined by different approaches in measuring it, and spanning different economic and social issues, as well as the levels of analysis. At a micro-level, poverty is commonly measured at the household level, utilizing income-based approach which remains the core concept at present (Munoz-Boudet, 2018). More recently developed measures of poverty stress the multi-dimensional aspect of poverty, implying experience of personal deprivation in terms of economic, social, poiltical and psychological traits (Misturelly and Heffernan, 2008). The most wellknown example of such measures is the Multidimensional Poverty Index developed by Alkire and Santos (2014) which comprises three equally weighted poverty dimensions - health, education and living standard captured by a number of indicators.

In our study we employ both subjective and objective measures of povety using EBRD LiTS Survey data for 2016. Household income in the survey provides an indication of what sort of goods and services families are able to afford. For subjective measure of poverty we use a 10-step poverty ladder variable, which reflects subjective ranking of a household's social standing ${ }^{4}$. Respondents in LiTS III were asked to "imagine a 10-step ladder where on the bottom, the first step, stand the poorest 10 per cent of people in [your country] and on the highest step, the tenth, stand the richest 10 per cent of people in [your country]. " They were then asked to state on which step of the 10-step ladder

\footnotetext{
${ }^{3}$ We also merged the third wave of the LiTS survey with the second one (2010). However, unlike the 2016 which offers measures of both subjective and objective poverty, the 2010 has only a subjective measure of poverty that prevents scholars to undertake full-scale comparisons across the two waves.

${ }^{4}$ EBRD (2016) Life in Transition report III, available from litsonline-EBRD.com
} 
they believe their household currently rests. We contrast this measure of subjective poverty perception with objective one, based on using data on individual net incomes. To enable compatibility between the two measures, we transform net income to generate an objective poverty ladder reflecting 10 deciles of net income distribution of respondents.

Additionally, as part of our robustness checks, we generate a threshold measure of poverty reflecting 20 centile of income distribution of both subjective and objective measures of poverty. It is defined as a binary variable denoting probability of respondents to fall within the bottom 20 per cent of income distribution.

\subsection{Measuring entrepreneurial activity}

The majority of studies available at a macro-level utilize either the rate of self-employment or new registered businesses from World Bank, or the Total Entrepreneurial Activity (TEA) data from Global Entrepreneurship Monitor (GEM) as a measure for entrepreneurial activity (Parker, 2018). The advantage of using the latter is to be able to distinguish between opportunity and necessity-driven entrepreneurship. Similarly, following Henrekson and Sanadaji (2014) we distinguish between selfemployment (low-value adding activity often triggered by entry due to a necessity motive), and business ownership with employment coined here as the 'Schumpetarian' entrepreneurship), utilizing the data on employment status of respondents. Respectively, based on EBRD LiTs data we distinsuish between (a) unemployed; (b) self-employed and (c) business owners with employment, where the latter two categories serve as our measures of low-value adding (self-employment) and high-value adding entrepreneurship (business ownership with employment) respectively. We set the 'employed for wages' as our reference category.

\subsection{Other variables and controls}


Among other variables of interest for testing our key set of hypotheses, we focus on gender which is measured by using a dummy variable equal one if a respondent is a female, and zero - being a male. At individual level we additionally control for the age of respondents; marital status; location (urban vs. rural); and education attainment.

In this study we also introduce various controls to capture the effect of different dimensions of local infrastructure development on combating poverty. We distinguish between hard infrastructure (i.e. physical infrastructure) and soft infrastructure, exemplified by various institutional structures and social frameworks. We control for their effect at an individual, regional (district-country) and country levels.

As regards the impact of institutional structures, the last decade saw significant transformations taking place in regions worldwide with the changes in governance structures and infrastructure reshaping the distribution of power, resources and welfare in cities and regions, making some of them thrive while others to decline. This is particularly emblematic for the post-socialist countries, with some of them riddled by economic hardships and poverty, deficient institutions, ethnic conflicts, - manifesting all the core factors that cause mass migration, further impoverishment, and cultural decay. Improvement in the quality of institutions should be associated with poverty reduction. However, this is not always the case as institutional reforms are costly to implement, and it is often the poor who bear higher transactions associated with implementation of institutional reforms (Chong and Calderon, 2000).

In countries with weak formal institutions, there is a wider meso-level variation in social relations (Efendic et al., 2015) where actions and beliefs of people are shaped not only by the network structure of an individual's social relations, but also normative structures that enable people to act collectively with their relations being governed by intergroup contracts (Pettogrew, 1998). In exploring the social roots of regional development our paper investigates the relationship of the two types of social capital, namely bonding and bridging, on individuals' subjective and objective poverty 
measures. While bonding (i.e. ties with family and community) is shown to render short-term gains in addressing various institutional deficiencies, weak ties, measured here via institutional trust act as bridges across different communities, fostering knowledge sharing and the diffusion of trust, therefore benefiting the process of development in a long run via improving social quality through mitigation of labour precariousness (Sabattini, 2008).

We measure the development of the physical infrastructure by looking at the level of satisfaction with tap water provision; electricity; telephone; central heating and gas. At an individual level we construct a scale variable of all these dimensions of physical infrastructure development with the alpha reliability test statistic equal to $0.82 \mathrm{We}$ also aggregate the individual-level dimensions of satisfaction with physical infrastructure to a NUTS3-country level to capture the meso-level effect of the hard infrastructure development. To capture the effect of the soft infrastructure development we capture the 'bonding' social capital via family trust (Q4.05a LiTS2016) and neighbourhood trust (Q 4.05b LiTS2016), using dichotomous variables with one denoting trust in close family members and neighbourhood respectively, and zero otherwise. The bridging social capital (i.e. institutional trust) is constructed as a scale variable based on the following dimensions: the presidency; the government/cabinet of ministers; the regional and local government; the parliament; court; political parties; army and the police. Such scale construction is validated by the alpha reliability test statistic being equal to 0.93 .

At a district-country level, we also control for the extent of informality of the economy which is likely to be associated with the deprived environment and the higher presence of low-value adding business with the constrained access to formal resources (Greene, 2008). All together, in locations where prevalence of informal contracts is high, we are less likely to observe poverty reduction.

At a country level we control for the quality of institutions, measured here by a composite index of World Wide Governance Indicators (WWGI, World Bank), reflecting various dimensions of the institutional environment of an individual country, including (a) Control for corruption; (b) 
Government effectiveness; (c) Political stability; (d) Regulatory quality; (e) Rule of law; (f) Voice \& Accountability. All these dimensions are highly collinear, so we construct their scale with alpha reliability test statistic being equal to 0.97 .

Finally, we also control for macroeconomic indicators such as the level of economic development and GDP growth rate. We lag country-level institutional and macroeconomic variables by one year to allow for some time to elapse prior to realisation of their effect on poverty alleviation. Our constructed index of institutional quality is highly correlated with GDP per capita (0.81) which is well above a common cut-off point of 0.7 . We therefore run our models using an alternative control for the level of development - a set of GDP pc dummies denoting the five quintiles of its distribution, which individually are not highly correlated with an index of institutional quality.

For further definition of these variables and descriptive statistics see Table 1. The correlation matrix of all variables used in estimation is reported in Table 2.

\section{\{INSERT Table $1 \& 2$ ABOUT HERE $\}$}

\subsection{Methodology}

To obtain our results we employ an ordered probit model, using a 10-point ladder measures of poverty. Following Ahlstrom et al. (2013) we additionally undertake some robustness checks, using a probit model with focus on narrower measures of poverty based on the $20^{\text {th }}$ centile-threshold of poverty ladder distribution. Since our data has hierarchical structure given that individuals are not randomly distributed across and within geographical districts and countries, they are more likely to exhibit similar characteristics or patterns of behavior within their areas of local (Estrin et al. 2013; Chasco and Gallo, 2013).

Thus, our baseline selection equation can be written as follows:

$$
\begin{aligned}
& \text { Poverty }_{i j k}=\alpha_{0}+\alpha_{1} \text { l4. }_{\text {poverty }} \text { pojk }_{1}+\alpha_{1} \text { urban }_{i j k}+\alpha_{2} \text { age }_{i j k}+ \\
& \alpha_{3} \text { age_sq }_{i j k}+\alpha_{4} \text { marital status }_{i j k}+\alpha_{5} \text { gender }_{i j k}+\alpha_{6} \text { unemployed }_{i j k}+
\end{aligned}
$$




$$
\begin{aligned}
& \alpha_{7} \text { self_employed }_{i j k}+\alpha_{8} \text { business_owner }_{i j k}+\alpha_{9} \text { internet_access }_{i j k}+ \\
& +\alpha_{10} \text { education }_{i j k}+\alpha_{11} \text { family_trust }_{i j k}+\alpha_{12} \text { NUTS3_family_trust }_{j k}+ \\
& \alpha_{13} \text { neighbourhood_trust }{ }_{i j k}+\alpha_{14} \text { NUTS3_neighbourhood_trust }{ }_{j k}+\alpha_{15} \text { instit_trust }_{i j k}+ \\
& \alpha_{16} \text { NUTS3_instit_trust }_{j k}+\alpha_{17} \text { NUTS3_informal_contract }{ }_{j k}+\alpha_{18} \text { l. instit_quality }{ }_{k}+ \\
& \alpha_{19} \text { l.iq } 2_{k}+\alpha_{20} \text { l.iq3 } 3_{k}+\alpha_{21} \text { l.iq4 } 4_{k}+\alpha_{22} \text { l.iq5 } 5_{k}+\alpha_{23} \text { l.GDPpc growth } h_{k}+e_{i j k}+g_{j k}+v_{k}
\end{aligned}
$$

where Poverty $_{i j k}$ is a respective measure of poverty. We control for the initial level of poverty reported by respondents as of four years ago (l4.poverty $y_{i j k}$; the operator 14 . indicates that this variable is lagged by four years). Variables with sub-scripts ijk denote individual-level variables, whereas variables with subscripts $j k$ and $k$ denote respectively NUTS3 and country-level variables. The operator $l$. is added to country-level variables to denote that a variable is lagged by one year.

The combination of $e_{i j k}+g_{j k}+v_{k}$ is the random part of the equation, where $v_{k}$ are the country level residuals, $g_{j k}$ are the NUTS3 (district-level) residuals, and $e_{i j k}$ represents individual-level residuals.

We also interact gender with each of employment status variables to test the linkages between entrepreneurship-gender and poverty.

\section{Empirical Results}

Table 3 below contains the results from using subjective (Models $1 \& 3$ ) and objective (models $2 \&$ 4) measures of poverty based on a 10-step ladder of income distribution. These models are used to test Hypotheses 1-2 (Models 1-2), and 3 (Models 3-4). Table 4 reports marginal effects related to our key variables of interest which come across as significant determinants of poverty alleviation.

\{INSERT Table 3 ABOUT HERE\} 
First of all, across various specifications reported in Table 3 we find strong and largely consistent support for hypothesis H1b, showing positive and significant effect of business ownership on poverty reduction. The marginal effects results reported in Table 4 suggest that entrepreneurial business owners are 0.5 percentage points more likely than paid employees to self-perceive themselves at the top 10 per cent of income distribution, and about 1 percentage points less likely to be at the bottom of subjective income ladder distribution (see Model 1 reported within the Business Ownership column in Table 4). In terms of the economic magnitude of this effect, the results are much stronger when we employ the objective measure of poverty based on a net income reported by respondents, where business owners' probability to be at the top level of distribution surges to 13 percentage points.

\section{\{INSERT Table 4 ABOUT HERE\}}

At the same time, consistently across all specifications we do not find any significant association between self-employment and poverty reduction (hypothesis H1a). When interpreted jointly with the business ownership results, this sheds some light on the importance of different types of entrepreneurial activity for economic growth and poverty with emphasizing the importance of highvalue adding activity as opposed to low-value adding entrepreneurship, confirming hypothesis H1c. Finally, as expected we find unemployment associated with the bottom of the poverty ladder distribution.

The gender results based on different measures of poverty, used in this study, reveal some controversy. Thus, using a subjective measure of poverty we do not observe gender gap in income distribution, implying similarity in perception of income distribution between men and women. However, using objective measure of poverty based on net income reported by respondents, being a female is strongly associated with a lower position on poverty ladder of income distribution. For more in-depth understanding of these results we turn again to the marginal effects results reported in Table 
4, contrasting predicted margins of the effects for females versus males. Being female instead of male increases respondent's probability of being at the bottom of income distribution by 0.5 percentage points, and respectively reduces probability of being at the top of income distribution by 1 percentage points (see Model 2 within the Gender column in Table 4). This provides partial (using objective measure of poverty) support for Hypothesis 2, although in terms of the economic magnitude of this effect, these results reveal only marginal differences between females in males.

When we turn to examining the interaction term results (Models 3 and 4 in Table 3), we find that female business-owners are likely to be richer than their male counterparts (Model 4, based on the objective measure of poverty). Being female business-owner increases probability to be at the top of income distribution by 6.8 percentage points (see Table 4 last column, outcome 10). Therefore, we also partly (using the objective measure of poverty and focusing on business ownership with employment creation) support Hypothesis 3.

We turn now to exploring cross country-group differences (Table 5). First, the results using a 10step poverty ladder of income distribution reveal the following. Consistently across all specifications, we find a positive effect of business ownership on poverty reduction. Second, being female retains its significance and positive association with lower position on poverty ladder of income distribution in the case of Central Europe and Baltic States, but not elsewhere. The positive association of unemployed status of females with subjective poverty is found in all country groups except for South Eastern Europe, implying that unemployed females on average are better off than their male counterparts.

\section{\{INSERT Table 5 ABOUT HERE $\}$}

Finally, we turn to Table 6 which provides some robustness checks for our results using a narrower definition of poverty. Table 6 reports the results based on the probit model looking at the probability of respondents falling within the bottom quintile of income distribution. First of all, the 
results on business ownership lose their significance, implying that we do not have many cases where the 20 per cent of poorest individuals happen to be business owners. Second, we find that the gender differences are almost erased retaining their marginal significance in the CEB region in the case of objective measure of poverty only. This further strengthens the evidence in support of Hypothesis $\mathrm{H} 2$. However, we get some contrasting results illustrating the regional differences: in the CEB region self-employed females are likely to be more associated with the bottom 20 per cent of income distribution, using subjective measure of poverty, whereas in the CA region, based on a net income measure of poverty (objective poverty), they are richer than their male counterparts, although the results are only marginally significant at 10 per cent level of significance. We do not find any significant regional gender differences in business ownership affecting poverty alleviation. Overall, these findings partly reject our Hypotheses $\mathrm{H} 4 \mathrm{a}$ and $\mathrm{H} 4 \mathrm{~b}$.

\section{\{INSERT Table 6 ABOUT HERE $\}$}

In addition to this main set of the results we also obtain some other interesting results on other determinants of poverty.

First, we find that individuals higher up the poverty ladder tend to be better educated; having access to internet; married, being about middle-age.

Satisfaction with the physical infrastructure development at an individual level is positively related to poverty reduction. However, as regards the aggregated-NUTs3 effect this result holds only in the case of $\mathrm{CEB}$ countries, using subjective measure of poverty. We also find strong support for the importance of institutional trust at individual-level, but negative effect at a NUTS3 level, in particular in the context of the CA region, showing, perhaps, that at the district-aggregated level the costs of institutional reforms are likely to disproportionally negatively affect the poorest in the CA region. Finally, we find some positive linking between inbound trust (bonding social capital), proxied by trusting family and neighbourhood at an individual level, but primarily insignificant at a district 
level of aggregation. The prevalence rate of individuals with informal contractual arrangements in a district is strongly associated with a higher state of impoverishment.

Finally, at a country-level we find positive effect of the overall institutional quality on poverty reduction, using objective measure of poverty. As regards to cross-region-country differences, we only observe the positive effect of a better quality of institutional environment on poverty reduction in the context of EEA region (based on using objective measure of poverty). Interestingly enough, while GDPpc economic growth is important for the overall sample of transition economies for climbing the poverty ladder, its effect is only significant in CEB and EEA regions, using subjective measures of poverty.

\section{Discussion}

Using the recent wave of the EBRD Life in Transition Survey III (2016) data, this study explored empirically the relationship between poverty alleviation, entrepreneurship and gender. While entrepreneurship has been increasingly recongnized as an important channel for combating poverty, an empirical evidence to support this claim, and also to shed more light on gender differences in shaping this relationship remains scarce. Our findings can be summarized as follows.

First of all, we found strong support for business ownership leading to reduction in poverty, though the benefits seem to accrue primarily to inividuals at a higher level than bottom qunitile of poverty ladder of income distirbution. This may be attributed to the important role the accumulation of the financial, human and social resources plays in facilitating high-growth potential new venture creation. The phenomenon of business ownership with job creation among the lowest quintile of income-based poverty ladder distribution is still fairly rare, that leads to insignificant results. However, as evidenced by the main results based on the full poverty ladder distribution, business ownership comes across consistenly positive and significant for transition economies, suggesting that 
high-potential entrepreneurship with ambitions to create jobs appears to be an effective instrument for policy-makers for impoving individuals' wealfare.

Second, we do not find any significant association between self-employment and poverty reduction, emphasizing the overall greater importance of higher-potential entrepreneurship as opposed to subsistence entrepreneurship in combating poverty.

Third, our findings provide some evidence for reduction of gender poverty gap. The poverty gap to a disadvatage of females appears to be minimal, manifesting only in the CEB region, but not elsewhere across transition region. Interestingly, when we narrow our focus down to poverty occurrence defined based on the $20^{\text {th }}$ centile of subjective and objective income distribution, we find some contrasting regional differences. More specifically, in the context of Central Europe and the Baltic States (CCB), we find that females engaged in self-employment are more likely to be associated with the lower $20^{\text {th }}$ centile of income ladder distribution, whereas the opposite holds for the region of Central Asia, although the latter results are only marginally significant. This implies that self-employment in the context of the CA region may provide some opportunties to females to climb the poverty ladder, but in the context of the CEB, it is likely to be viewed as subsistence entrepeneurship where females resort to it because there are no alternative labour market opportunities available.

Based on this discussion, our findings make important contributions to the literature of entrepreneurship, poverty and gender studies. First of all, we develop a theoretical argument claiming a differentiatial effect played by different types of entrepreneurial activity on poverty alleviation, and further test this empirically, utilizing the unique cross-individual, cross-region and cross-country EBRD Life in Transition Survey data for 2016. Second, this study also provides fairly novel and rich evidence on gender differences in the setting of transition economies, and illustrates to what extent engaging in entrepreneurial activity may economically empower women to climb up the poverty 
ladder in this region. Therefore, this paper fills some important gaps in the poverty and gender studies literature, offering new insights on gender-entrepreneurship-poverty relationship in the context of emerging economies of Central and Eastern Europe, and Central Asia.

\section{Conclusions}

Poverty reduction remains a critical agenda for policy-makers worldwide, urging academic scholars to search for new evidence on effective measures for fighting poverty. This study extends the understanding of the mechanism via which entrepreneurial process is likely to contribute to poverty reduction in transition region, distinguishing between subsistence and Schumpeterian entrepreneurship. It also provides some interesting findings on gender differences in entrepreneurship-poverty relationship, suggesting that increasing female participation in entrepreneurship can be one of the effective measures to increase females' welfare in the region. Overall, our study has important ramifications for researchers and policy makers. For researchers, it suggests that it is important to distinguish between different types of entrepreneurial activity in studying the poverty agenda, specifically across different regions. For policy-makers it offers new insights on the greater importance of higher-potential entrepreneurship as opposed to subsistence entrepreneurship in combating poverty, and the important role entrepreneurship plays in empowering females in climbing up the poverty ladder. Our study is an early effort in offering a comparative perspective on differences across various regions of transition economies, calling for furture qualitative and quantitative research in studying regional differences in more detail. 


\section{References:}

Ahlstrom, D. and Z. Ding. 2014. "Entrepreneurship in China: an overview." International Small Business Journal 32 (6): 610-618. doi:10.1177/0266242613517913.

Ahlstrom, D., G.D. Bruton, and L. Zhao. 2013. "Turning good research into good publications." Nankai Business Review International $4 \quad$ (2): 92-106. doi: $10.1108 / 20408741311323317$.

Aidis, R., S. Estrin, and T. Mickiewicz. 2008. "Institutions and entrepreneurship development in Russia: a comparative perspective." Journal of Business Venturing 23 (6): 656-672. doi: 10.1016/j.jbusvent.2008.01.005.

Alam, A., M. Murthi, R. Yemtsov, E. Murrugarra, N. Dudwick, E. Hamilton. and E. Tiongson. 2005. Growth, poverty, and inequality: Eastern Europe and the former Soviet Union. The World Bank: Washington, D.C. http://documents.worldbank.org/curated/en/750511468295836867/Growthpoverty-and-inequality-Eastern-Europe-and-the-Former-Soviet-Union.

Ashwin, S., 2010. "Understanding the gender dynamics of Russia's economic transformation: women's and men's experiences of employment, domestic labour and poverty." In The international handbook of gender and poverty: Concepts, research, policy, edited by Sylvia Chant, 178-183. Northampton, Mass.: Edward Elgar Publishing.

Baumol, W. 1990. "Entrepreneurship: productive, unproductive, and destructive." Journal of Political Economy 98 (5, Part I): 893-921. doi: 10.1016/0883-9026(94)00014-X.

Berkowitz, D. and J.E. Jackson. 2006. "Entrepreneurship and the evolution of income distributions in Poland and Russia." Journal of Comparative Economics 34 (2): 338-356.

Blackburn, R. and M. Ram. 2006. "Fix or fixation? The contributions and limitations of entrepreneurship and small firms to combating social exclusion." Entrepreneurship and Regional Development 18(1): 73-89. doi: doi.org/10.1016/j.jce.2006.02.003.

Bruton, G. D., D. Ahlstrom, and S. Si. 2015. "Entrepreneurship, poverty, and Asia: Moving beyond subsistence entrepreneurship." Asia Pacific Journal of Management 32(1): 1-22. doi: 10.1007/s10490-014-9404-X. 
Bruton, G. D., S. Khavul and H. Chavez. 2011. "Microlending in emerging economies: Building a new line of inquiry from the ground up." Journal of International Business Studies 42(5): 718-739. doi: 10.1057/jibs.2010.58.

Bruton, G.D., D.J. Ketchen Jr, and R.D. Ireland. 2013. "Entrepreneurship as a solution to poverty." Journal of Business Venturing 28(6): 683-689. doi: 10.1016/j.jbusvent.2013.05.002.

Chong, A., and C. Calderon. 2000. "Institutional quality and distribution of income." Economic Development and Cultural Change 48 (4): 761-786. doi:10.1086/452476.

Dollar, D., and A. Kraay, 2013. Growth still is good for the poor. World Bank Policy Research Working Paper. doi:10.1596/1813-9450-6568.

Duflo, E. 2012. "Women empowerment and economic development." Journal of Economic Literature 50 (4): 1051-79. doi: 10.1257/jel.50.4.1051.

Efendic, A., T. Mickiewicz, and A. Rebmann,. 2015. "Growth aspirations and social capital: Young firms in a post-conflict environment." International Small Business Journal 33(5): 537-561. doi: $10.1177 / 0266242613516987$.

Estrin, S. and T. Mickiewicz. 2011. "Institutions and Female Entrepreneurship." Small Business Economics 37(4): 397. doi: 10.1007/s11187-011-9373-0.

Estrin, S. and T. Mickiewicz. 2011. "Entrepreneurship in transition economies: the role of institutions and generational change." In The Dynamics of Entrepreneurship, edited by Marie Minniti, 293-338. Oxford: Oxford University Press.

Estrin, S., J. Korosteleva, and T. Mickiewicz. 2013. "Which institutions encourage entrepreneurial growth aspirations?" Journal of Business Venturing 28(4): 564-580. doi: 10.1016/j.jbusvent.2012.05.001.

Falkingham, J. and A. Baschieri, 2010. "Gender, poverty and transition in Central Asia." In The international handbook of gender and poverty: Concepts, research, policy, edited by Sylvia Chant, 184-189. Northampton, Mass.: Edward Elgar Publishing.

Frankish, J. S., R. G. Roberts, A. Coad, and D. J. Storey. 2014. "Is entrepreneurship a route out of deprivation?” Regional Studies 48(6): 1090-1107. Doi: 10.1080/00343404.2013.871384

GEM. Global Entrepreneurship Monitor Report 2015-16, available from, http://www.gemconsortium.org/report. 
Greene, F, J., K. M. Mole, and D. J. Storey, D. J., 2008. Three Decades of Enterprise Culture: Economic Regeneration and Public Policy. London: Macmillan.

Harris, C., 2004. Control and subversion: Gender relations in Tajikistan. London: Pluto Press.

Henrekson, M., and T. Sanandaji. 2014. "Small business activity does not measure entrepreneurship." Proceedings of the National Academy of Sciences of the USA, http://www.pnas.org/content/early/2014/01/15/1307204111.abstract.

Jukkala, T., I. H. Mäkinen, O. Kislllitsyna, S. Ferlander and D. Vägero. 2008. "Economic strain, social relations, gender and binge drinking in Moscow." Social Science and Medicine 66(3): 663-74. doi: 10.1016/j.socscimed.2007.10.017.

Korosteleva, J. and M. Belitski. 2017. "Entrepreneurial dynamics and higher education institutions in the post-Communist world." Regional Studies 51(3): 439-453. doi: 10.1080/00343404.2015.1103370 Khavul, S., H. Chavez, and G. D. Bruton. 2013. "When institutional change outruns the change agent: The contested terrain of entrepreneurial microfinance for those in poverty." Journal of Business Venturing 28(1): 30-50. doi: 10.1016/j.jbusvent.2012.02.005.

Manolova, T., R. Eunni, and B. Gyoshev. 2008. "Institutional Environments for Entrepreneurship: Evidence from Emerging Economies in Eastern Europe.” Entrepreneurship Theory and Practice 32(1): 203-218. doi: 10.1111/j.1540-6520.2007.00222.x

McCloskey, D.N. 2010. Bourgeois dignity: Why economics can't explain the modern world. Chicago, Ill; London: University of Chicago Press.

McMullen, J.S. 2010. "Delineating the domain of development entrepreneurship: a market-based approach to facilitating inclusive economic growth." Entrepreneurship Theory and Practice 35(1), 185-215. doi: 10.1111/j.1540-6520.2010.00428.x

Mickiewicz, T. 2010. Economics of Institutional Change: Central and Eastern Europe Revisited, $2^{\text {nd }}$ ed., Basingstoke: Palgrave Macmillan.

Milanovic, B. 1998. Income, inequality, and poverty during the transition from planned to market economy. Washington, DC: World Bank.

Munoz-Boudet, A.M.M., P. Buitrago, B. L. de la Briere, D. Newhouse, E.R. Matulevich, K. Scott, and P. Suarez-Becerra. 2018. Gender differences in poverty and household composition through the life-cycle. World Bank WPS8360. doi: 10.1596/1813-9450-8360. 
Parker, S. 2018. The Economics of Entrepreneurship. Second edition. Cambridge: Cambridge University Press.

Phelps E.S. 2013. Mass Flourishing: How Grassroots Innovation Created Jobs, Challenge and Change. Princeton, NJ: Princeton University Press.

Prahalad, C. K. 2005. Fortune at the bottom of the pyramid: Eradicating poverty through profits. Upper Saddle River: Wharton School Publishing.

Rosser, J. B. Jr., M. V. Rosser, and E. Ahmed. 2000. "Income Inequality and the Informal Economy in Transition Economies." Journal of Comparative Economics 28(1): 156-171. doi: 10.1006/jcec.2000.1645.

Sabarwal, S., and K. Terrell. 2008. "Does gender matter for firm performance? evidence from Eastern Europe and Central Asia.” Policy Research working paper; no. WPS 4705. Washington, DC: World Bank.

Sabatini, F. 2008. "Social capital and the quality of economic development.” Kyklos 61(3): 466-499. doi: 10.1111/j.1467-6435.2008.00413.x

Sanchez, C. 2018. 'No, 70\% of the world's poor aren't women, but that does not mean poverty isn't sexist." Word Bank Development Blog. Accessed 12 September 2018. http://blogs.worldbank.org/developmenttalk/no-70-world-s-poor-aren-t-women-doesn-t-meanpoverty-isn-t-sexist

Sattar, S. 2011. "Opportunities for Men and Women: Emerging Europe and Central Asia." World Bank OKR. Accessed 12 September 2018.

https://openknowledge.worldbank.org/handle/10986/2800.

Schumpeter, J. 1934 [2008]. The Theory of Economic Development. Brunswick, NJ: Transaction Publishers.

Scott, L., C. Dolan, M. Johnstone-Lois, K. Sugden, and M. Wu. 2012. "Enterprise and inequality: a study of Avon in South Africa." Entrepreneurship Theory and Practice 36, 544-568. doi: 10.1111/j.1540-6520.2012.00507.x

Si, S., X. Yu, A. Wu, S. Chen, S. Chen, and Y. Su. 2015. "Entrepreneurship and poverty reduction: A case study of Yiwu, China." Asia Pacific Journal of Management 32(1): 119-143. doi: 10.1007/s10490-014-9395-7. 
Simai, M., 2006. "Poverty and inequality in eastern Europe and the CIS transition economies." UN Department of Economic and Social Affairs Working Papers. Accessed on 17 November 2018. http://www.un.org/esa/desa/papers/2006/wp17_2006.pdf.

Smallbone, D., and F. Welter. 2001. "The distinctiveness of entrepreneurship in transition economies.” Small Business Economics 16(4): 249-262. doi: 10.1023/A:1011159216578

Tomizawa, A., L. Zhao, G. Bassellier, and D. Ahlstrom. 2019. "Economic growth, innovation, institutions, and the Great Enrichment." Asia Pacific Journal of Management 36, forthcoming. doi: 10.1007/s10490-019-09648-2.

Valliere, D., and R. Peterson. 2009. "Entrepreneurship and economic growth: Evidence from emerging and developed countries." Entrepreneurship \& Regional Development, 21(5-6): 459-480. doi: 10.1080/08985620802332723.

Welter, F., D. Smallbone, E. Aculai, N. Isakova, and N. Schakirova. 2003. "Female entrepreneurship in Post-Soviet Countries." In New Perspectives on Women Entrepreneurs, edited by John E. Butler, 243-269. Greenwich, CT: Information Age Publishing.

Welter, F. and D. Smallbone, 2011. "Institutional Perspective on Entrepreneurial Behaviour in Challenging Environments." Journal of Small Business Management 49(1): 107-125. doi: 10.1111/j.1540-627X.2010.00317.x

World Bank. 2017. Monitoring Global Poverty. Report of the Commission on Global Poverty. $\begin{array}{llll}\text { Accessed } & 10 & \text { August } & \text { Available at: }\end{array}$ https://openknowledge.worldbank.org/bitstream/handle/10986/25141/9781464809613.pdf.

Wu, J. and S. Si. 2018. "Poverty reduction through entrepreneurship: incentives, social networks, and sustainability." Asian Business \& Management, 17(4): 243-259. doi: 10.1057/s41291-018-0039-5 
Table 1: Definitions of the variables and descriptive statistics

\begin{tabular}{|c|c|c|c|c|c|c|}
\hline Variable & LiTS Questions & Obs. & Mean & $\begin{array}{l}\text { Std. } \\
\text { Dev. }\end{array}$ & Min & Max \\
\hline \multicolumn{7}{|c|}{ Dependent variables } \\
\hline $\begin{array}{l}\text { Subjective } \\
\text { poverty ladder }\end{array}$ & $\begin{array}{l}\text { Q3.15: imagine a 10-step ladder where on the bottom, the first step, stand the poorest } \\
10 \text { per cent of people in [your country] and on the highest step, the tenth, stand the } \\
\text { richest } 10 \text { per cent of people in [your country] }\end{array}$ & 41342 & 4.5 & 1.7 & 1 & 10 \\
\hline $\begin{array}{l}\text { Objective } \\
\text { poverty ladder }\end{array}$ & $\begin{array}{l}\text { Q2.23: What is the total net monthly income of your household at present? } \\
\text { Note: This is calculated as the total sum of income of all household members received } \\
\text { from wages, pensions, social and family benefits, regular transfers from persons } \\
\text { outside the household and from other sources. The variable was transformed by taking } \\
10 \text { centile of income distribution by country. }\end{array}$ & 33,057 & 5.32 & 2.85 & 1 & 10 \\
\hline \multicolumn{7}{|c|}{ Independent variables } \\
\hline Unemployed & $\begin{array}{l}\text { Q5.15 Occupation type } \\
\text { Employment_status is equal to } 1 \text { if the respondent is unemployed }\end{array}$ & 20,113 & 0.09 & 0.29 & 0 & 1 \\
\hline Self-employed & Employment_status is equal to 2 if the respondent is self-employed (Q5.15=5) & 20,113 & 0.06 & 0.23 & 0 & 1 \\
\hline Business owner & Employment_status is equal to 3 if the respondent is an employer (Q5.15=4) & 20,113 & 0.024 & 0.15 & 0 & 1 \\
\hline Gender & Gender status $($ female $=1$ and male $=0)(\mathrm{Q} 1.03)$ & 42,178 & 0.57 & 0.49 & 0 & 1 \\
\hline \multicolumn{7}{|c|}{ Controls } \\
\hline \multicolumn{7}{|c|}{ Individual-level characteristics } \\
\hline Urban & Urbanity status (urban $=1$ and rural $=0$ ) & 42,178 & 0.55 & 0.49 & 0 & 1 \\
\hline Age & Q1.04: What is your age? & 42,178 & 49 & 17 & 18 & 95 \\
\hline Married & Q7.01 Marital status (married=1 and otherwise $=0$ ) & 42,178 & .58 & .49 & 0 & 1 \\
\hline Education & $\begin{array}{l}\text { Q1.09: What is your education? The variable takes values from 1='no education' to } \\
7=\text { MA/PhD level' }\end{array}$ & 42,178 & 4.4 & 1.5 & 1 & 7 \\
\hline Internet access & Q2.04: Do you have access to internet at home, & 42,178 & 0.63 & 0.48 & 0 & 1 \\
\hline
\end{tabular}




\begin{tabular}{|c|c|c|c|c|c|c|}
\hline & inclusively on a smartphone? & & & & & \\
\hline Family trust & Q4.05a: To what extent do you trust family? & 38,328 & 0.96 & 0.2 & 0 & 1 \\
\hline $\begin{array}{l}\text { Neighborhood } \\
\text { Trust }\end{array}$ & Q4.05b: To what extent do you trust neighborhood? & 41,754 & 0.71 & 0.45 & 0 & 1 \\
\hline Institutional trust & $\begin{array}{l}\text { Q4.04: To what extent do you trust the following institutions... } \\
\text { (a) The Presidency; (b) The Government/Cabinet Ministers; (c) Regional } \\
\text { Government; (d) Local Government; (e) The Parliament; (f) Courts; (g) Political } \\
\text { Parties; (h) Armed Forces; (i) The Police } \\
\text { A scale of all these questions is constructed }\end{array}$ & 41,651 & 0.019 & 0.82 & -1.93 & 1.78 \\
\hline \multicolumn{7}{|c|}{ Regional (NUTS3)-level controls } \\
\hline $\begin{array}{l}\text { Family trust } \\
\text { (NUTS3-country) }\end{array}$ & Aggregated to NUTS3-country level & 42,178 & 0.96 & 0.04 & 0.25 & 1 \\
\hline $\begin{array}{l}\text { Neighbourhood } \\
\text { trust } \\
\text { (NUTS3-country) }\end{array}$ & Aggregated to NUTS3-country level & 42,178 & 0.71 & 0.12 & 0 & 1 \\
\hline $\begin{array}{l}\text { Institutional trust } \\
\text { (NUTS3-country) }\end{array}$ & Averaged at NUTS3-country level & 42,178 & 0.001 & 0.96 & -2.57 & 3.58 \\
\hline $\begin{array}{l}\text { Informal contract } \\
\text { arrangements } \\
\text { (NUTS3-country) }\end{array}$ & $\begin{array}{l}\text { Q 5.16 What type of contractual arrangement do you have with your employer? A } \\
\text { response 'informal' has been coded as equal to } 1 \text {. The responses are averaged at } \\
\text { NUTS3-country level }\end{array}$ & 42,138 & 0.13 & 0.155 & 0 & 1 \\
\hline \multicolumn{7}{|c|}{ Country-level controls } \\
\hline $\begin{array}{l}\text { Institutional } \\
\text { quality }\end{array}$ & $\begin{array}{l}\text { World Bank World Wide Governance Indicators (percentile rankings): (a) Control for } \\
\text { corruption; (b) Government effectiveness; (c) Political stability; (d) Regulatory } \\
\text { quality; (e) Rule of law; (f) Voice \& Accountability. A scale of all } 6 \text { variables is } \\
\text { constructed. }\end{array}$ & 42,177 & -.11 & .93 & -1.76 & 1.35 \\
\hline $\begin{array}{l}\text { GDP per capita } \\
\text { constant } 2010 \text { US } \\
\text { dollars }\end{array}$ & $\begin{array}{l}\text { World Bank World Development Indicators, 2018. It is split further into five quintile } \\
\text { groups (iq1-iq5, where iq1 is set as reference category) }\end{array}$ & 42,177 & 9039.881 & 6357.5 & 932.9 & 23781.3 \\
\hline $\begin{array}{l}\text { GDP growth } \\
\text { (annual \%) }\end{array}$ & World Bank World Development Indicators, 2018. & 42,177 & 2.1 & 3.2 & -9.9 & 8 \\
\hline
\end{tabular}


Table 2: Correlation matrix

\begin{tabular}{|c|c|c|c|c|c|c|c|c|c|c|c|c|c|c|c|c|c|c|c|c|c|c|c|c|c|c|c|}
\hline Variables & (1) & (2) & (3) & (4) & (5) & (6) & (7) & (8) & (9) & (10) & (11) & (12) & (13) & (14) & (15) & (16) & (17) & (18) & (19) & (20) & (21) & (22) & (23) & (24) & (25) & (26) & (27) \\
\hline $\begin{array}{l}\text { Subjective } \\
\text { poverty ladder(1) }\end{array}$ & 1 & & & & & & & & & & & & & & & & & & & & & & & & & & \\
\hline $\begin{array}{l}\text { Objective poverty } \\
\text { ladder (2) }\end{array}$ & $\begin{array}{l}36 \\
(.00) \\
\end{array}$ & 1 & & & & & & & & & & & & & & & & & & & & & & & & & \\
\hline Unemployed (3) & $\begin{array}{l}-.17 \\
(.00)\end{array}$ & $\begin{array}{l}-.23 \\
(.00)\end{array}$ & 1 & & & & & & & & & & & & & & & & & & & & & & & & \\
\hline $\begin{array}{l}\text { Self-employed } \\
\text { (4) }\end{array}$ & $\begin{array}{l}.01 \\
(.18)\end{array}$ & $\begin{array}{l}.00 \\
(.96) \\
\end{array}$ & $\begin{array}{l}.08 \\
(.00) \\
\end{array}$ & 1 & & & & & & & & & & & & & & & & & & & & & & & \\
\hline $\begin{array}{l}\text { Business owner } \\
\text { (5) }\end{array}$ & $\begin{array}{l}.09 \\
(.00)\end{array}$ & $\begin{array}{l}.094 \\
(.00)\end{array}$ & $\begin{array}{l}-.05 \\
(.00)\end{array}$ & $\begin{array}{l}-.04 \\
(.00) \\
\end{array}$ & 1 & & & & & & & & & & & & & & & & & & & & & & \\
\hline $\begin{array}{l}\text { Gender } \\
(\text { Female=1) (6) }\end{array}$ & $\begin{array}{l}-.04 \\
(.00) \\
\end{array}$ & $\begin{array}{l}-.09 \\
(.00) \\
\end{array}$ & $\begin{array}{l}-.01 \\
(.25) \\
\end{array}$ & $\begin{array}{l}-.05 \\
(.00) \\
\end{array}$ & $\begin{array}{l}-.06 \\
(.00) \\
\end{array}$ & 1 & & & & & & & & & & & & & & & & & & & & & \\
\hline Urban (7) & $\begin{array}{l}.03 \\
(.00)\end{array}$ & $\begin{array}{l}.13 \\
(.00)\end{array}$ & $\begin{array}{l}.05 \\
(.00)\end{array}$ & $\begin{array}{l}-.04 \\
(.00)\end{array}$ & $\begin{array}{l}.04 \\
(.00)\end{array}$ & $\begin{array}{l}.04 \\
(.00)\end{array}$ & 1 & & & & & & & & & & & & & & & & & & & & \\
\hline Age (8) & $\begin{array}{l}-.17 \\
(.00)\end{array}$ & $\begin{array}{l}-.29 \\
(.00)\end{array}$ & $\begin{array}{l}.00 \\
. .54)\end{array}$ & $\begin{array}{l}.04 \\
(.00)\end{array}$ & $\begin{array}{l}.02 \\
(.00)\end{array}$ & $\begin{array}{l}.05 \\
.00)\end{array}$ & $\begin{array}{l}.00 \\
(.54)\end{array}$ & 1 & & & & & & & & & & & & & & & & & & & \\
\hline Education (9) & $\begin{array}{l}.18 \\
(.00)\end{array}$ & $\begin{array}{l}.32 \\
(.00) \\
\end{array}$ & $\begin{array}{l}-.12 \\
(.00) \\
\end{array}$ & $\begin{array}{l}-.05 \\
(.00) \\
\end{array}$ & $\begin{array}{l}.02 \\
(.00) \\
\end{array}$ & $\begin{array}{l}-.00 \\
(.40) \\
\end{array}$ & $\begin{array}{l}.17 \\
(.00) \\
\end{array}$ & $\begin{array}{l}-.21 \\
(.00) \\
\end{array}$ & 1 & & & & & & & & & & & & & & & & & & \\
\hline Married (10) & $\begin{array}{l}.08 \\
(.00)\end{array}$ & $\begin{array}{l}.26 \\
(.00) \\
\end{array}$ & $\begin{array}{l}-.00 \\
(.60)\end{array}$ & $\begin{array}{l}.03 \\
(.00)\end{array}$ & $\begin{array}{l}.03 \\
(.00) \\
\end{array}$ & $\begin{array}{l}-.13 \\
(.00)\end{array}$ & $\begin{array}{l}-.09 \\
(.00)\end{array}$ & $\begin{array}{l}.03 \\
(.00) \\
\end{array}$ & $\begin{array}{l}.02 \\
(.00)\end{array}$ & 1 & & & & & & & & & & & & & & & & & \\
\hline $\begin{array}{l}\text { Internet access } \\
\text { (11) }\end{array}$ & $\begin{array}{l}.26 \\
(.00) \\
\end{array}$ & $\begin{array}{l}.44 \\
(.00) \\
\end{array}$ & $\begin{array}{l}-.14 \\
(.00) \\
\end{array}$ & $\begin{array}{l}-.02 \\
(.00) \\
\end{array}$ & $\begin{array}{l}.03 \\
(.00) \\
\end{array}$ & $\begin{array}{l}-.04 \\
(.00) \\
\end{array}$ & $\begin{array}{l}.14 \\
(.00) \\
\end{array}$ & $\begin{array}{l}-.36 \\
(.00) \\
\end{array}$ & $\begin{array}{l}.27 \\
(.00) \\
\end{array}$ & $\begin{array}{l}.05 \\
(.00) \\
\end{array}$ & 1 & & & & & & & & & & & & & & & & \\
\hline $\begin{array}{l}\text { Physical } \\
\text { infrastructure } \\
\text { (12) }\end{array}$ & $\begin{array}{l}.11 \\
(.00)\end{array}$ & $\begin{array}{l}.07 \\
(.00)\end{array}$ & $\begin{array}{l}.08 \\
(.00)\end{array}$ & $\begin{array}{l}.03 \\
(.00)\end{array}$ & $\begin{array}{l}.01 \\
(.26)\end{array}$ & $\begin{array}{l}.01 \\
(.02)\end{array}$ & $\begin{array}{l}.09 \\
(.00)\end{array}$ & $\begin{array}{l}.06 \\
(.00)\end{array}$ & $\begin{array}{l}.05 \\
(.00)\end{array}$ & $\begin{array}{l}.06 \\
(.00)\end{array}$ & $\begin{array}{l}.07 \\
(.00)\end{array}$ & 1 & & & & & & & & & & & & & & & \\
\hline $\begin{array}{l}\text { Physical } \\
\text { infrastructure } \\
\text { (NUTS3-country) } \\
\text { (13) }\end{array}$ & $\begin{array}{l}.05 \\
(.00)\end{array}$ & $\begin{array}{l}.06 \\
(.00)\end{array}$ & $\begin{array}{l}-.10 \\
(.00)\end{array}$ & $\begin{array}{l}-.02 \\
(.00)\end{array}$ & $\begin{array}{l}-.01 \\
(.17)\end{array}$ & $\begin{array}{l}.03 \\
(.00)\end{array}$ & $\begin{array}{l}.15 \\
(.00)\end{array}$ & $\begin{array}{l}.11 \\
(.00)\end{array}$ & $\begin{array}{l}.03 \\
(.00)\end{array}$ & $\begin{array}{l}-.13 \\
(.00)\end{array}$ & $\begin{array}{l}.12 \\
(.00)\end{array}$ & $\begin{array}{l}39 \\
(.00)\end{array}$ & 1 & & & & & & & & & & & & & & \\
\hline Family trust (14) & $\begin{array}{l}.03 \\
(.00) \\
\end{array}$ & $\begin{array}{l}.07 \\
(.00) \\
\end{array}$ & $\begin{array}{l}.00 \\
(.96) \\
\end{array}$ & $\begin{array}{l}.01 \\
(.31) \\
\end{array}$ & $\begin{array}{l}.01 \\
(.24) \\
\end{array}$ & $\begin{array}{l}.01 \\
(.01) \\
\end{array}$ & $\begin{array}{l}.00 \\
(.82) \\
\end{array}$ & $\begin{array}{l}.02 \\
(.00) \\
\end{array}$ & $\begin{array}{l}.02 \\
(.00) \\
\end{array}$ & $\begin{array}{l}.04 \\
(.00) \\
\end{array}$ & $\begin{array}{l}.03 \\
(.00) \\
\end{array}$ & $\begin{array}{ll}.04 \\
(.00) \\
\end{array}$ & $\begin{array}{l}.01 \\
(.17) \\
\end{array}$ & 1 & & & & & & & & & & & & & \\
\hline $\begin{array}{l}\text { Neighborhood } \\
\text { Trust (15) }\end{array}$ & $\begin{array}{l}.04 \\
(.00) \\
\end{array}$ & $\begin{array}{l}.00 \\
(.80) \\
\end{array}$ & $\begin{array}{l}-.01 \\
(.15)\end{array}$ & $\begin{array}{l}.01 \\
(.14) \\
\end{array}$ & $\begin{array}{l}.01 \\
(.06) \\
\end{array}$ & $\begin{array}{l}-.01 \\
(.26) \\
\end{array}$ & $\begin{array}{l}.08 \\
(.00)\end{array}$ & $\begin{array}{l}.08 \\
(.00) \\
\end{array}$ & $\begin{array}{l}-.01 \\
(.06) \\
\end{array}$ & $\begin{array}{l}.04 \\
(.00)\end{array}$ & $\begin{array}{l}.04 \\
(.00) \\
\end{array}$ & $\begin{array}{l}.04 \\
(.00)\end{array}$ & $\begin{array}{l}-.02 \\
(.00) \\
\end{array}$ & $\begin{array}{l}.22 \\
(.00)\end{array}$ & 1 & & & & & & & & & & & & \\
\hline $\begin{array}{l}\text { Institutional trust } \\
\text { (16) }\end{array}$ & $\begin{array}{l}.12 \\
(.00)\end{array}$ & $\begin{array}{l}.01 \\
(.13)\end{array}$ & $\begin{array}{l}-.05 \\
(.00)\end{array}$ & $\begin{array}{l}-.01 \\
(.08)\end{array}$ & $\begin{array}{l}0.01 \\
(.19)\end{array}$ & $\begin{array}{l}.02 \\
(.00)\end{array}$ & $\begin{array}{l}.15 \\
(.00)\end{array}$ & $\begin{array}{l}-.03 \\
(.00)\end{array}$ & $\begin{array}{l}.03 \\
(.00)\end{array}$ & $\begin{array}{l}.05 \\
(.00)\end{array}$ & $\begin{array}{l}-.12 \\
(.00)\end{array}$ & $\begin{array}{l}.08 \\
(.00)\end{array}$ & $\begin{array}{l}-.07 \\
(.00)\end{array}$ & $\begin{array}{l}.06 \\
(.00)\end{array}$ & $\begin{array}{l}.19 \\
(.00)\end{array}$ & 1 & & & & & & & & & & & \\
\hline $\begin{array}{l}\text { Family trust } \\
\text { (NUTS3- } \\
\text { country) (17) }\end{array}$ & $\begin{array}{l}.01 \\
(.14)\end{array}$ & $\begin{array}{l}.01 \\
(.09)\end{array}$ & $\begin{array}{l}.03 \\
(.00)\end{array}$ & $\begin{array}{l}-.00 \\
(.66)\end{array}$ & $\begin{array}{l}.01 \\
(.24)\end{array}$ & $\begin{array}{l}.00 \\
(.40)\end{array}$ & $\begin{array}{l}-.02 \\
(.00)\end{array}$ & $\begin{array}{l}.02 \\
(.00)\end{array}$ & $\begin{array}{l}.05 \\
(.00)\end{array}$ & $\begin{array}{l}.03 \\
(.00)\end{array}$ & $\begin{array}{l}-.04 \\
(.00)\end{array}$ & $\begin{array}{l}-.01 \\
(.02)\end{array}$ & $\begin{array}{l}.07 \\
(.00)\end{array}$ & $\begin{array}{l}.05 \\
(.00)\end{array}$ & $\begin{array}{l}.09 \\
(.00)\end{array}$ & $\begin{array}{l}.11 \\
(.00)\end{array}$ & 1 & & & & & & & & & & \\
\hline $\begin{array}{l}\text { Neighbourhood } \\
\text { trust }\end{array}$ & $\begin{array}{l}-.02 \\
(.00) \\
\end{array}$ & $\begin{array}{l}.00 \\
(.81) \\
\end{array}$ & $\begin{array}{l}.07 \\
(.00) \\
\end{array}$ & $\begin{array}{l}.03 \\
(.00) \\
\end{array}$ & $\begin{array}{l}.01 \\
(.07) \\
\end{array}$ & $\begin{array}{l}-.01 \\
(.02) \\
\end{array}$ & $\begin{array}{l}-.19 \\
(.00) \\
\end{array}$ & $\begin{array}{l}-.00 \\
(.32) \\
\end{array}$ & $\begin{array}{l}.06 \\
(.00) \\
\end{array}$ & $\begin{array}{l}.08 \\
(.00) \\
\end{array}$ & $\begin{array}{l}-.12 \\
(.00) \\
\end{array}$ & $\begin{array}{l}.07 \\
(.00) \\
\end{array}$ & $\begin{array}{l}-.17 \\
(.00) \\
\end{array}$ & $\begin{array}{l}.07 \\
(.00) \\
\end{array}$ & $\begin{array}{l}.07 \\
(.00) \\
\end{array}$ & $\begin{array}{l}.19 \\
(.00) \\
\end{array}$ & $\begin{array}{l}0.32 \\
(.00) \\
\end{array}$ & 1 & & & & & & & & & \\
\hline
\end{tabular}




\begin{tabular}{|c|c|c|c|c|c|c|c|c|c|c|c|c|c|c|c|c|c|c|c|c|c|c|c|c|c|c|c|}
\hline $\begin{array}{l}\text { (NUTS3- } \\
\text { country) (18) }\end{array}$ & & & & & & & & & & & & & & & & & & & & & & & & & & & \\
\hline $\begin{array}{l}\text { Institutional trust } \\
\text { (NUTS3-country) } \\
\text { (19) }\end{array}$ & $\begin{array}{l}.05 \\
(.00)\end{array}$ & $\begin{array}{l}-.02 \\
(.00)\end{array}$ & $\begin{array}{l}-.01 \\
(.32)\end{array}$ & $\begin{array}{l}.02 \\
(.03)\end{array}$ & $\begin{array}{l}.01 \\
(.14)\end{array}$ & $\begin{array}{l}.01 \\
(.09)\end{array}$ & $\begin{array}{l}-.10 \\
(.00)\end{array}$ & $\begin{array}{l}-.10 \\
(.00)\end{array}$ & $\begin{array}{l}.04 \\
(.00)\end{array}$ & $\begin{array}{l}.09 \\
(.00)\end{array}$ & $\begin{array}{l}-.17 \\
(.00)\end{array}$ & $\begin{array}{l}-.04 \\
(.00)\end{array}$ & $\begin{array}{l}.13 \\
(.00)\end{array}$ & $\begin{array}{l}.05 \\
(.00)\end{array}$ & $\begin{array}{l}.10 \\
(.00)\end{array}$ & $\begin{array}{l}.56 \\
(.00)\end{array}$ & $\begin{array}{l}.18 \\
(.00)\end{array}$ & $\begin{array}{l}.37 \\
(.00)\end{array}$ & 1 & & & & & & & & \\
\hline $\begin{array}{l}\text { Informal contract } \\
\text { arrangements } \\
\text { (NUTS3-country) } \\
\text { (20) }\end{array}$ & $\begin{array}{l}-.05 \\
(.00)\end{array}$ & $\begin{array}{l}.04 \\
. .00)\end{array}$ & $\begin{array}{l}.04 \\
(.00)\end{array}$ & $\begin{array}{l}.04 \\
(.00)\end{array}$ & $\begin{array}{l}.02 \\
(.03)\end{array}$ & $\begin{array}{l}-.02 \\
(.00)\end{array}$ & $\begin{array}{l}-.09 \\
(.00)\end{array}$ & $\begin{array}{l}-.13 \\
(.00)\end{array}$ & $\begin{array}{l}.04 \\
(.00)\end{array}$ & $\begin{array}{l}.12 \\
(.00)\end{array}$ & $\begin{array}{l}-.06 \\
(.00)\end{array}$ & $\begin{array}{l}.17 \\
(.00)\end{array}$ & $\begin{array}{l}.31 \\
(.00)\end{array}$ & $\begin{array}{l}-.02 \\
(.00)\end{array}$ & $\begin{array}{l}.02 \\
(0.00 \\
)\end{array}$ & $\begin{array}{l}.03 \\
(.00)\end{array}$ & $\begin{array}{l}.01 \\
(.01)\end{array}$ & $\begin{array}{l}.03 \\
(.00)\end{array}$ & $\begin{array}{l}.09 \\
(.00)\end{array}$ & 1 & & & & & & & \\
\hline $\begin{array}{l}\text { Institutional } \\
\text { quality (21) }\end{array}$ & $\begin{array}{l}.01 \\
(.13) \\
\end{array}$ & $\begin{array}{l}.02 \\
(.00) \\
\end{array}$ & $\begin{array}{l}-.01 \\
(.05) \\
\end{array}$ & $\begin{array}{l}-.01 \\
(.42) \\
\end{array}$ & $\begin{array}{ll}.02 \\
(.01) \\
\end{array}$ & $\begin{array}{l}.01 \\
(.09) \\
\end{array}$ & $\begin{array}{l}.04 \\
(.00) \\
\end{array}$ & $\begin{array}{l}.21 \\
(.00) \\
\end{array}$ & $\begin{array}{l}-.11 \\
(.00) \\
\end{array}$ & $\begin{array}{l}-.17 \\
(.00) \\
\end{array}$ & $\begin{array}{l}.13 \\
(.00) \\
\end{array}$ & $\begin{array}{l}.21 \\
(.00) \\
\end{array}$ & $\begin{array}{l}.44 \\
(.00) \\
\end{array}$ & $\begin{array}{l}-.00 \\
(.39)\end{array}$ & $\begin{array}{l}-.00 \\
(.39)\end{array}$ & $\begin{array}{l}-.16 \\
(.00)\end{array}$ & $\begin{array}{l}-.14 \\
(.00)\end{array}$ & $\begin{array}{l}-.16 \\
(.00)\end{array}$ & $\begin{array}{l}-.29 \\
(.00)\end{array}$ & $\begin{array}{l}-.48 \\
(.00)\end{array}$ & 1 & & & & & & \\
\hline $\begin{array}{l}\text { GDP growth } \\
\text { (annual \%) (22) }\end{array}$ & $\begin{array}{l}.06 \\
(.00) \\
\end{array}$ & $\begin{array}{l}-.01 \\
(.76) \\
\end{array}$ & $\begin{array}{l}.07 \\
(.00) \\
\end{array}$ & $\begin{array}{l}.04 \\
(.00) \\
\end{array}$ & $\begin{array}{l}.03 \\
(.00) \\
\end{array}$ & $\begin{array}{l}-.03 \\
(.00) \\
\end{array}$ & $\begin{array}{l}-.12 \\
(.00) \\
\end{array}$ & $\begin{array}{l}.02 \\
(.00) \\
\end{array}$ & $\begin{array}{l}-.18 \\
(.00) \\
\end{array}$ & $\begin{array}{l}.06 \\
(.00) \\
\end{array}$ & $\begin{array}{l}.09 \\
(.00) \\
\end{array}$ & $\begin{array}{l}-.05 \\
(.00) \\
\end{array}$ & $\begin{array}{l}-.16 \\
(.00) \\
\end{array}$ & $\begin{array}{l}.07 \\
(.00) \\
\end{array}$ & $\begin{array}{l}.07 \\
(.00) \\
\end{array}$ & $\begin{array}{l}.22 \\
(.00) \\
\end{array}$ & $\begin{array}{l}.16 \\
(.00) \\
\end{array}$ & $\begin{array}{l}.26 \\
(.00) \\
\end{array}$ & $\begin{array}{l}36 \\
(.00) \\
\end{array}$ & $\begin{array}{l}-.18 \\
(.00) \\
\end{array}$ & $\begin{array}{l}20 \\
(.00) \\
\end{array}$ & 1 & & & & & \\
\hline $\begin{array}{l}\text { GDP per capita } \\
\text { constant } 2010 \text { US } \\
\text { dollars (iq1) (23) }\end{array}$ & $\begin{array}{l}.04 \\
(.00)\end{array}$ & $\begin{array}{l}.01 \\
(.14)\end{array}$ & $\begin{array}{l}.08 \\
(.00)\end{array}$ & $\begin{array}{l}.03 \\
(.00)\end{array}$ & $\begin{array}{l}.00 \\
(.99)\end{array}$ & $\begin{array}{l}-.01 \\
(.26)\end{array}$ & $\begin{array}{l}-.13 \\
(.00)\end{array}$ & $\begin{array}{l}.10 \\
(.00)\end{array}$ & $\begin{array}{l}.06 \\
(.00)\end{array}$ & $\begin{array}{l}.13 \\
(.00)\end{array}$ & $\begin{array}{l}-.12 \\
(.00)\end{array}$ & $\begin{array}{l}-.22 \\
(.00)\end{array}$ & $\begin{array}{l}-.46 \\
(.00)\end{array}$ & $\begin{array}{l}.03 \\
(.00)\end{array}$ & $\begin{array}{l}.03 \\
(.00)\end{array}$ & $\begin{array}{l}.03 \\
(.00)\end{array}$ & $\begin{array}{l}.15 \\
(.00)\end{array}$ & $\begin{array}{l}.30 \\
(.00)\end{array}$ & $\begin{array}{l}.10 \\
(.00)\end{array}$ & $\begin{array}{l}.36 \\
(.00)\end{array}$ & $\begin{array}{l}-.64 \\
(.00)\end{array}$ & $\begin{array}{l}.02 \\
(.00)\end{array}$ & 1 & & & & \\
\hline $\begin{array}{l}\text { GDP per capita } \\
\text { constant } 2010 \text { US } \\
\text { dollars (iq2) (24) }\end{array}$ & $\begin{array}{l}-.003 \\
(.58)\end{array}$ & $\begin{array}{l}-.01 \\
(.06)\end{array}$ & $\begin{array}{l}.05 \\
(.00)\end{array}$ & $\begin{array}{l}.05 \\
(.00)\end{array}$ & $\begin{array}{l}-.00 \\
(.98)\end{array}$ & $\begin{array}{l}-.02 \\
(.00)\end{array}$ & $\begin{array}{l}.03 \\
(.00)\end{array}$ & $\begin{array}{l}-.06 \\
(.00)\end{array}$ & $\begin{array}{l}-.09 \\
(.00)\end{array}$ & $\begin{array}{l}.10 \\
(.00)\end{array}$ & $\begin{array}{l}-.02 \\
(.00)\end{array}$ & $\begin{array}{l}-.07 \\
(.00)\end{array}$ & $\begin{array}{l}-.1 \\
(.00)\end{array}$ & $\begin{array}{l}-.04 \\
(.00)\end{array}$ & $\begin{array}{l}-.04 \\
(.00)\end{array}$ & $\begin{array}{l}-.01 \\
(.29)\end{array}$ & $\begin{array}{l}-.11 \\
(.00)\end{array}$ & $\begin{array}{l}-.09 \\
(.00)\end{array}$ & $\begin{array}{l}-.05 \\
(.00)\end{array}$ & $\begin{array}{l}.17 \\
(.00)\end{array}$ & $\begin{array}{l}-.08 \\
(.00)\end{array}$ & $\begin{array}{l}.04 \\
(.00)\end{array}$ & $\begin{array}{l}-.30 \\
(.00)\end{array}$ & 1 & & & \\
\hline $\begin{array}{l}\text { GDP per capita } \\
\text { constant } 2010 \text { US } \\
\text { dollars (iq3) (25) }\end{array}$ & $\begin{array}{l}.002 \\
(.66)\end{array}$ & $\begin{array}{l}.00 \\
(.81)\end{array}$ & $\begin{array}{l}-.06 \\
(.00)\end{array}$ & $\begin{array}{l}-.05 \\
(.00)\end{array}$ & $\begin{array}{l}-.02 \\
(.00)\end{array}$ & $\begin{array}{l}.01 \\
(.00)\end{array}$ & $\begin{array}{l}.11 \\
(.00)\end{array}$ & $\begin{array}{l}-.02 \\
(.00)\end{array}$ & $\begin{array}{l}.11 \\
(.00)\end{array}$ & $\begin{array}{l}.06 \\
(.00)\end{array}$ & $\begin{array}{l}.05 \\
(.00)\end{array}$ & $\begin{array}{l}.07 \\
(.00)\end{array}$ & $\begin{array}{l}.09 \\
(.00)\end{array}$ & $\begin{array}{l}-.01 \\
(.11)\end{array}$ & $\begin{array}{l}-.01 \\
(.11)\end{array}$ & $\begin{array}{l}-.01 \\
(.22)\end{array}$ & $\begin{array}{l}.03 \\
(.00)\end{array}$ & $\begin{array}{l}-.13 \\
(.00)\end{array}$ & $\begin{array}{l}-.01 \\
(.04)\end{array}$ & $\begin{array}{l}.06 \\
(.00)\end{array}$ & $\begin{array}{l}-.16 \\
(.00)\end{array}$ & $\begin{array}{l}-20 \\
(.00)\end{array}$ & $\begin{array}{l}-.30 \\
(.00)\end{array}$ & $\begin{array}{l}-.27 \\
(.00)\end{array}$ & 1 & & \\
\hline $\begin{array}{l}\text { GDP per capita } \\
\text { constant } 2010 \text { US } \\
\text { dollars (iq4) (26) }\end{array}$ & $\begin{array}{l}.03 \\
(.00)\end{array}$ & $\begin{array}{l}.01 \\
(.01)\end{array}$ & $\begin{array}{l}-.04 \\
(.00)\end{array}$ & $\begin{array}{l}-.03 \\
(.00)\end{array}$ & $\begin{array}{l}.03 \\
(.00)\end{array}$ & $\begin{array}{l}.02 \\
(.00)\end{array}$ & $\begin{array}{l}.05 \\
(.00)\end{array}$ & $\begin{array}{l}.14 \\
(.00)\end{array}$ & $\begin{array}{l}-.00 \\
(.54)\end{array}$ & $\begin{array}{l}-.13 \\
(.00)\end{array}$ & $\begin{array}{l}.06 \\
(.00)\end{array}$ & $\begin{array}{l}.15 \\
(.00)\end{array}$ & $\begin{array}{l}.36 \\
(.00)\end{array}$ & $\begin{array}{l}.03 \\
(.00)\end{array}$ & $\begin{array}{l}.03 \\
(.00)\end{array}$ & $\begin{array}{l}.02 \\
(.00)\end{array}$ & $\begin{array}{l}.04 \\
(.00)\end{array}$ & $\begin{array}{l}-.05 \\
(.00)\end{array}$ & $\begin{array}{l}.01 \\
(.12)\end{array}$ & $\begin{array}{l}-.33 \\
(.00)\end{array}$ & $\begin{array}{l}.64 \\
(.00)\end{array}$ & $\begin{array}{l}.10 \\
(.00)\end{array}$ & $\begin{array}{l}-.33 \\
(.00)\end{array}$ & $\begin{array}{l}-.30 \\
(.00)\end{array}$ & $\begin{array}{l}-.30 \\
(.00)\end{array}$ & 1 & \\
\hline $\begin{array}{l}\text { GDP per capita } \\
\text { constant } 2010 \text { US } \\
\text { dollars (iq5) (27) }\end{array}$ & $\begin{array}{l}.01 \\
(.00)\end{array}$ & $\begin{array}{l}.01 \\
(.30)\end{array}$ & $\begin{array}{l}-.04 \\
(.00)\end{array}$ & $\begin{array}{l}.03 \\
(.00)\end{array}$ & $\begin{array}{l}-.01 \\
(.10)\end{array}$ & $\begin{array}{l}-.02 \\
(.00)\end{array}$ & $\begin{array}{l}-.07 \\
(.00)\end{array}$ & $\begin{array}{l}.06 \\
(.00)\end{array}$ & $\begin{array}{l}.12 \\
(.00)\end{array}$ & $\begin{array}{l}.07 \\
(.00)\end{array}$ & $\begin{array}{l}.05 \\
(.00)\end{array}$ & $\begin{array}{l}.11 \\
(.00)\end{array}$ & $\begin{array}{l}.17 \\
(.00)\end{array}$ & $\begin{array}{l}.01 \\
(.03)\end{array}$ & $\begin{array}{l}-.01 \\
(.03)\end{array}$ & $\begin{array}{l}-.06 \\
(.00)\end{array}$ & $\begin{array}{l}.06 \\
(.00)\end{array}$ & $\begin{array}{l}-.06 \\
(.00)\end{array}$ & $\begin{array}{l}.09 \\
(.00)\end{array}$ & $\begin{array}{l}.22 \\
(.00)\end{array}$ & $\begin{array}{l}.37 \\
(.00)\end{array}$ & $\begin{array}{l}.16 \\
(.00)\end{array}$ & $\begin{array}{l}-.16 \\
(.00)\end{array}$ & $\begin{array}{l}-.14 \\
(.00)\end{array}$ & $\begin{array}{l}-.14 \\
(.00)\end{array}$ & $\begin{array}{l}.16 \\
(.00)\end{array}$ & 1 \\
\hline
\end{tabular}




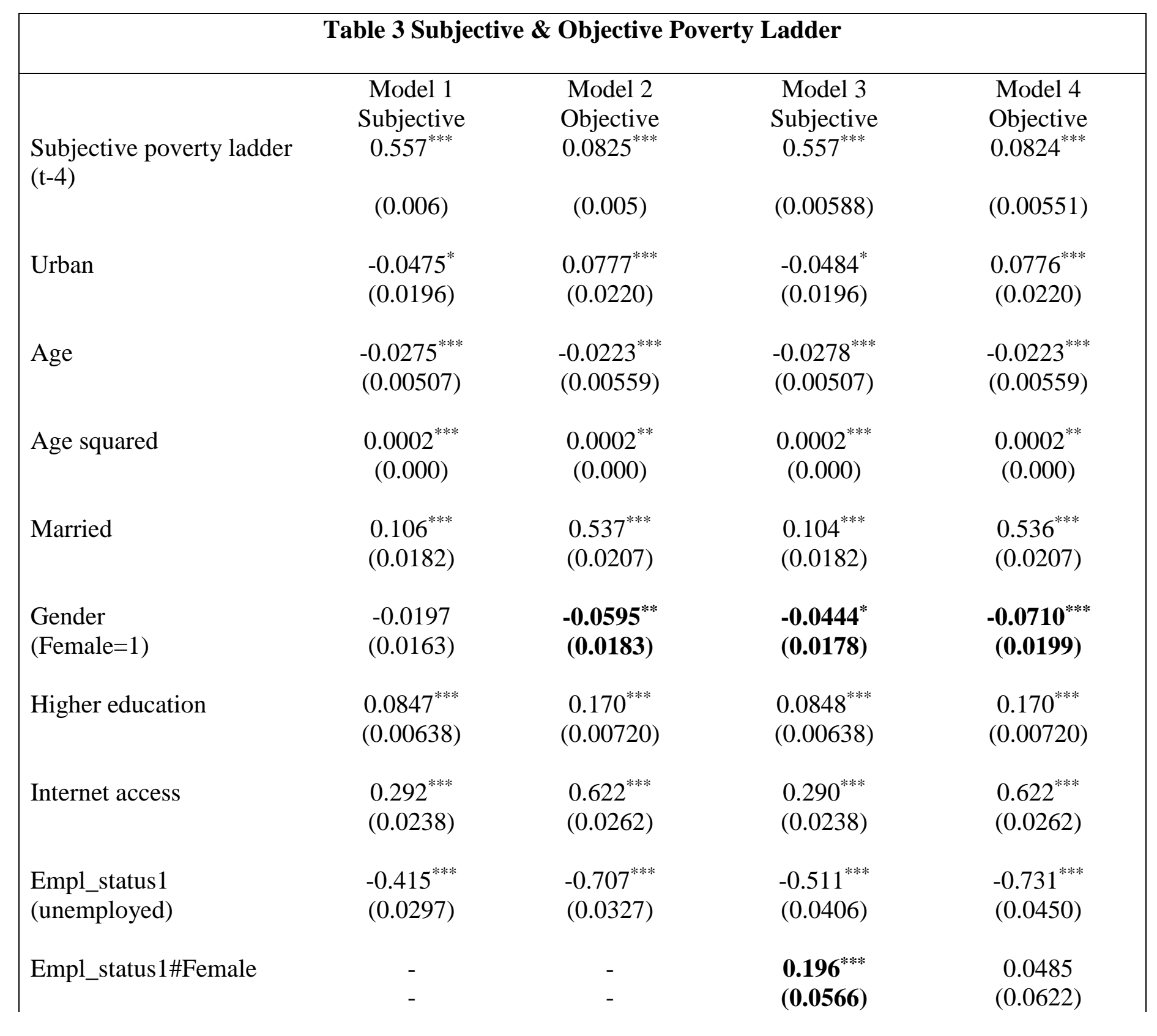




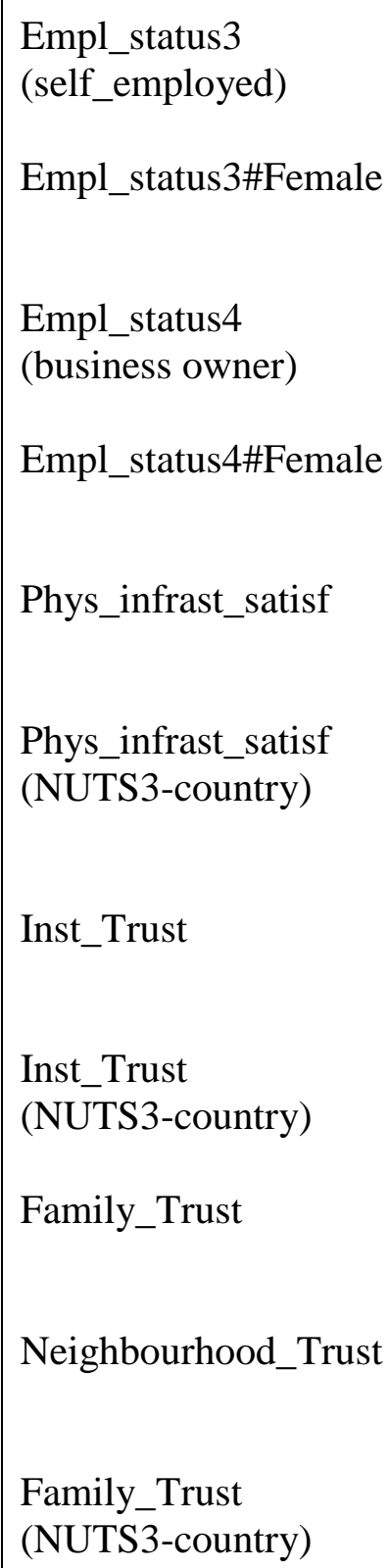

\begin{tabular}{|c|c|}
\hline $\begin{array}{c}0.0154 \\
(0.0354)\end{array}$ & $\begin{array}{c}0.0105 \\
(0.0409)\end{array}$ \\
\hline- & - \\
\hline- & - \\
\hline $\begin{array}{l}0.350^{* * * *} \\
(0.0523)\end{array}$ & $\begin{array}{c}0.611^{* * *} \\
(0.0653)\end{array}$ \\
\hline- & - \\
\hline- & - \\
\hline $\begin{array}{l}0.104^{* * *} \\
(0.0110)\end{array}$ & $\begin{array}{c}0.0533^{* * *} \\
(0.0122)\end{array}$ \\
\hline 0.00762 & 0.0306 \\
\hline$(0.0236)$ & $(0.0262)$ \\
\hline $\begin{array}{l}0.185^{* * *} \\
(0.0128)\end{array}$ & $\begin{array}{l}0.0437^{* *} \\
(0.0143)\end{array}$ \\
\hline $\begin{array}{c}-0.0237 \\
(0.0305)\end{array}$ & $\begin{array}{l}-0.0746^{*} \\
(0.0298)\end{array}$ \\
\hline $\begin{array}{c}0.0252 \\
(0.0443)\end{array}$ & $\begin{array}{l}0.268^{* * *} \\
(0.0508)\end{array}$ \\
\hline $\begin{array}{l}0.0505^{* *} \\
(0.0187)\end{array}$ & $\begin{array}{c}0.0253 \\
(0.0211)\end{array}$ \\
\hline $\begin{array}{c}-0.150 \\
(0.342)\end{array}$ & $\begin{array}{c}0.0759 \\
(0.381)\end{array}$ \\
\hline
\end{tabular}

$-0.0271$

(0.0451)

$-0.00996$ (0.0519)

0.0490 $(0.0815)$

(0.0707) (0.0815)

$0.320^{\text {**** }}$

$0.528^{* * * *}$ (0.0775)

$0.277^{+}$ (0.142)

0.0814

(0.111)

$0.0535^{* * * *}$

(0.0122)

(0.0110)

0.0306

$(0.0236)$

(0.0262)

$0.186^{* * *}$

$0.0438^{* * *}$

(0.0143)

$-0.0746^{*}$

(0.0298)

(0.0305)

$0.266^{* * * *}$

(0.0508)

(0.0443)

0.0263

(0.0211)

0.0859

(0.381) 


\begin{tabular}{|c|c|c|c|c|}
\hline $\begin{array}{l}\text { Neighbourhood_Trust } \\
\text { (NUTS3-country) }\end{array}$ & $\begin{array}{l}-0.185 \\
(0.152)\end{array}$ & $\begin{array}{r}-0.0669 \\
(0.176)\end{array}$ & $\begin{array}{l}-0.189 \\
(0.153)\end{array}$ & $\begin{array}{l}-0.0687 \\
(0.176)\end{array}$ \\
\hline $\begin{array}{l}\text { Informal_contract } \\
\text { (NUTS3-country) }\end{array}$ & $\begin{array}{l}-0.502^{* * *} \\
(0.124)\end{array}$ & $\begin{array}{l}-0.401^{* *} \\
(0.135)\end{array}$ & $\begin{array}{c}-0.504^{* * * *} \\
(0.124)\end{array}$ & $\begin{array}{l}-0.401^{* *} \\
(0.135)\end{array}$ \\
\hline $\begin{array}{l}\text { Institutional_quality } \\
\text { (country-level) (t-1) }\end{array}$ & $\begin{array}{c}-0.116 \\
(0.0733)\end{array}$ & $\begin{array}{c}0.128^{*} \\
(0.0648)\end{array}$ & $\begin{array}{c}-0.115 \\
(0.0733)\end{array}$ & $\begin{array}{c}0.128^{*} \\
(0.0647)\end{array}$ \\
\hline $\begin{array}{l}\text { GDP growth }(\mathrm{t}-1) \\
\text { (country-level) }\end{array}$ & $\begin{array}{l}0.0588^{* * *} \\
(0.00944)\end{array}$ & $\begin{array}{c}0.0145^{+} \\
(0.00812)\end{array}$ & $\begin{array}{l}0.0587^{* * *} \\
(0.00942)\end{array}$ & $\begin{array}{c}0.0145^{+} \\
(0.00811)\end{array}$ \\
\hline GDPpc (iq2) & $\begin{array}{r}-0.0789 \\
(0.109)\end{array}$ & $\begin{array}{l}-0.245^{*} \\
(0.0953)\end{array}$ & $\begin{array}{r}-0.0810 \\
(0.108)\end{array}$ & $\begin{array}{l}-0.245^{*} \\
(0.0952)\end{array}$ \\
\hline GDPpc (iq3) & $\begin{array}{l}-0.189^{+} \\
(0.0978)\end{array}$ & $\begin{array}{l}-0.283^{* * *} \\
(0.0817)\end{array}$ & $\begin{array}{l}-0.190^{+} \\
(0.0976)\end{array}$ & $\begin{array}{l}-0.283^{* * *} \\
(0.0816)\end{array}$ \\
\hline GDPpc (iq4) & $\begin{array}{c}0.00375 \\
(0.169)\end{array}$ & $\begin{array}{l}-0.273^{+} \\
(0.147)\end{array}$ & $\begin{array}{l}0.000171 \\
(0.169)\end{array}$ & $\begin{array}{l}-0.274^{+} \\
(0.147)\end{array}$ \\
\hline GDPpc (iq5) & $\begin{array}{l}-0.0258 \\
(0.201)\end{array}$ & $\begin{array}{l}-0.0965 \\
(0.175)\end{array}$ & $\begin{array}{l}-0.0298 \\
(0.200)\end{array}$ & $\begin{array}{l}-0.0958 \\
(0.175)\end{array}$ \\
\hline var(countryTE_num) & $\begin{array}{c}0.0103^{+} \\
(0.00623) \\
\end{array}$ & $\begin{array}{c}0.00140 \\
(0.00318) \\
\end{array}$ & $\begin{array}{c}0.0102 \\
(0.00620) \\
\end{array}$ & $\begin{array}{r}0.00136 \\
(0.00317) \\
\end{array}$ \\
\hline var(NUTS3_CountryTE) & $\begin{array}{l}0.129^{* * *} \\
(0.0121)\end{array}$ & $\begin{array}{l}0.165^{* * *} \\
(0.0147)\end{array}$ & $\begin{array}{l}0.130^{* * *} \\
(0.0121)\end{array}$ & $\begin{array}{l}0.165^{\text {**** }} \\
(0.0147)\end{array}$ \\
\hline$N$ & 17983 & 14103 & 17983 & 14103 \\
\hline
\end{tabular}


Table 4. Summary of key marginal effects based on the results reported in Table 3: Contrasts of Predictive Margins

\begin{tabular}{|c|c|c|c|c|c|c|c|c|c|c|}
\hline \multirow{2}{*}{$\begin{array}{c}\text { Variables } \\
\text { Ordinal } \\
\text { outcomes/model }\end{array}$} & \multicolumn{4}{|c|}{$\begin{array}{c}\text { Gender } \\
(\text { female }==1 \text { vs. } \text { male }=0)\end{array}$} & \multicolumn{4}{|c|}{$\begin{array}{c}\text { Business ownership (BO) } \\
(\mathrm{BO}=1 \text { vs. Paid Employment=0) }\end{array}$} & \multicolumn{2}{|c|}{$\begin{array}{c}\text { Gender_X_Business } \\
\text { Ownership } \\
\text { (Gender and BO interaction } \\
1 \text { vs. 0) }\end{array}$} \\
\hline & Model 1 & Model 2 & Model 3 & Model 4 & Model 1 & Model 2 & Model 3 & Model 4 & Model 3 & Model 4 \\
\hline $\begin{array}{c}1\left(10^{\text {th }} \text { bottom }\right. \\
\text { centile })\end{array}$ & $\begin{array}{l}.0007 \\
(.0006)\end{array}$ & $\begin{array}{l}.005 * * \\
(.001)\end{array}$ & $\begin{array}{l}-.0002 \\
(.0006)\end{array}$ & $\begin{array}{l}.005 * * \\
(.002)\end{array}$ & $\begin{array}{c}-.010 * * * \\
(.001)\end{array}$ & $\begin{array}{c}-.033 * * * \\
(.003)\end{array}$ & $\begin{array}{c}-.010 * * * \\
(.0013)\end{array}$ & $\begin{array}{c}-.035 * * * \\
(.003)\end{array}$ & $\begin{array}{l}-.002 \\
(.002)\end{array}$ & $\begin{array}{c}-.012 * * \\
(.004)\end{array}$ \\
\hline $2\left(20^{\text {th }}\right.$ centile $)$ & $\begin{array}{c}.001 \\
(.001)\end{array}$ & $\begin{array}{l}.003 * * \\
(.001)\end{array}$ & $\begin{array}{l}.0008 \\
(.001)\end{array}$ & $\begin{array}{l}.003 * * * \\
(.001)\end{array}$ & $\begin{array}{c}-.017 * * * \\
(.0022)\end{array}$ & $\begin{array}{c}-.027 * * * \\
(.002)\end{array}$ & $\begin{array}{c}- \\
.0172 * * * \\
(.0023)\end{array}$ & $\begin{array}{l}-.028 * * * \\
(.002)\end{array}$ & $\begin{array}{l}-.004 \\
(.005)\end{array}$ & $\begin{array}{l}-.010^{*} \\
(.004)\end{array}$ \\
\hline $3\left(30^{\text {th }}\right.$ centile $)$ & $\begin{array}{l}.002 \\
(.002)\end{array}$ & $\begin{array}{l}.004 * * \\
(.001)\end{array}$ & $\begin{array}{l}.002 \\
(.002)\end{array}$ & $\begin{array}{c}.004 * * * \\
(.001)\end{array}$ & $\begin{array}{c}-.033 * * * \\
(.005)\end{array}$ & $\begin{array}{c}-.037 * * * \\
(.003)\end{array}$ & $\begin{array}{c}-.034 * * * \\
(.005)\end{array}$ & $\begin{array}{c}-.04 * * * \\
(.004)\end{array}$ & $\begin{array}{l}-.008 \\
(.01)\end{array}$ & $\begin{array}{l}-.015^{*} \\
(.007)\end{array}$ \\
\hline $4\left(40^{\text {th }}\right.$ centile $)$ & $\begin{array}{l}.001 \\
(.001)\end{array}$ & $\begin{array}{l}.003 * * \\
(.001)\end{array}$ & $\begin{array}{l}.0024^{*} \\
(.001)\end{array}$ & $\begin{array}{l}.003 * * * \\
(.001)\end{array}$ & $\begin{array}{c}-.027 * * * \\
(.004)\end{array}$ & $\begin{array}{c}-.032 * * * \\
(.003)\end{array}$ & $\begin{array}{c}- \\
.0278 * * * \\
(.0047) \\
\end{array}$ & $\begin{array}{c}-.034 * * * \\
(.003)\end{array}$ & $\begin{array}{l}-.007 \\
(.009)\end{array}$ & $\begin{aligned}-.014^{*} \\
(.007)\end{aligned}$ \\
\hline $5\left(50^{\text {th }}\right.$ centile $)$ & $\begin{array}{l}-.001 \\
(.001)\end{array}$ & $\begin{array}{l}.003 * * \\
(.001)\end{array}$ & $\begin{array}{l}.0003 \\
(.001)\end{array}$ & $\begin{array}{c}.0028 * * \\
(.001)\end{array}$ & $\begin{array}{c}.003^{* * * *} \\
(.002)\end{array}$ & $\begin{array}{c}-.033 * * * \\
(.004)\end{array}$ & $\begin{array}{c}.0024 * * * \\
(.0017)\end{array}$ & $\begin{array}{c}-.036 * * * \\
(.0042) \\
\end{array}$ & $\begin{array}{l}-.00003 \\
(.0023) \\
\end{array}$ & $\begin{array}{l}-.015^{+} \\
(.008)\end{array}$ \\
\hline $6\left(60^{\text {th }}\right.$ centile $)$ & $\begin{array}{l}-.002 \\
(.001)\end{array}$ & $\begin{array}{l}.001 * * \\
(.0004)\end{array}$ & $\begin{array}{l}-.0019 \\
(.0013)\end{array}$ & $\begin{array}{l}.001^{*} \\
(.001)\end{array}$ & $\begin{array}{c}.027 * * * * \\
(.004)\end{array}$ & $\begin{array}{c}-.025 * * * \\
(.004)\end{array}$ & $\begin{array}{c}.027 * * * \\
(.004)\end{array}$ & $\begin{array}{c}-.028 * * * \\
(.004)\end{array}$ & $\begin{array}{l}.0062 \\
(.008)\end{array}$ & $\begin{array}{c}.014^{+} \\
(.008)\end{array}$ \\
\hline $7\left(70^{\text {th }}\right.$ centile $)$ & $\begin{array}{l}-.001 \\
(.001)\end{array}$ & $\begin{array}{c}-.0005^{* *} * \\
(.0002)\end{array}$ & $\begin{array}{c}-.002 \\
(.0012)\end{array}$ & $\begin{array}{c}-.001^{+} \\
(.0004)\end{array}$ & $\begin{array}{l}.028 * * * \\
(.0045)\end{array}$ & $\begin{array}{c}-.008 * * * \\
(.002)\end{array}$ & $\begin{array}{c}.029 * * * \\
(.005)\end{array}$ & $\begin{array}{c}-.0102 * * * \\
(.003)\end{array}$ & $\begin{array}{l}.0068 \\
(.009)\end{array}$ & $\begin{array}{c}-.007 \\
(.0055)\end{array}$ \\
\hline $8\left(80^{\text {th }}\right.$ centile $)$ & $\begin{array}{l}-.001 \\
(.001)\end{array}$ & $\begin{array}{c}-.003 * * \\
.001\end{array}$ & $\begin{array}{l}-.0012 \\
(.0008)\end{array}$ & $\begin{array}{c}-.003 * * * \\
(.001)\end{array}$ & $\begin{array}{c}.019 * * * \\
(.003)\end{array}$ & $\begin{array}{c}.013 * * * \\
(.001)\end{array}$ & $\begin{array}{l}.019 * * * \\
(.0035)\end{array}$ & $\begin{array}{c}.012 * * * \\
(.002)\end{array}$ & $\begin{array}{l}.0046 \\
(.007)\end{array}$ & $\begin{array}{l}.0005 \\
(.003)\end{array}$ \\
\hline $9\left(90^{\text {th }}\right.$ centile $)$ & $\begin{array}{l}-.0003 \\
(.0002)\end{array}$ & $\begin{array}{c}-.006^{* *} \\
(.002)\end{array}$ & $\begin{array}{l}-.0003 \\
(.0002)\end{array}$ & $\begin{array}{c}-.006 * * * \\
(.0018)\end{array}$ & $\begin{array}{c}.005^{* * * *} \\
(.001)\end{array}$ & $\begin{array}{c}.052 * * * \\
(.004)\end{array}$ & $\begin{array}{c}.006^{* * * *} \\
(.001)\end{array}$ & $\begin{array}{c}.054 * * * \\
(.004)\end{array}$ & $\begin{array}{l}.0014 \\
(.002)\end{array}$ & $\begin{array}{l}.018^{*} \\
(.007)\end{array}$ \\
\hline $\begin{array}{l}10\left(10^{\text {th }} \text { top }\right. \\
\text { centile })\end{array}$ & $\begin{array}{l}-.0002 \\
(.0002)\end{array}$ & $\begin{array}{l}-.01 * * \\
(.003)\end{array}$ & $\begin{array}{l}-.0003 \\
(.0002)\end{array}$ & $\begin{array}{c}-.009 * * \\
(.003)\end{array}$ & $\begin{array}{c}.005 * * * \\
(.001)\end{array}$ & $\begin{array}{c}.131 * * * \\
(.017)\end{array}$ & $\begin{array}{c}.005 * * * \\
(.001)\end{array}$ & $\begin{array}{c}.145 * * * \\
(.019)\end{array}$ & $\begin{array}{c}.001 \\
(.002)\end{array}$ & $\begin{array}{l}.068^{+} \\
(.039)\end{array}$ \\
\hline
\end{tabular}

Note: Ordinal outcomes correspond to the respective centile of the poverty ladder distribution. For example, outcome 1 corresponds to the $10^{\text {th }}$ bottom centile of poverty ladder distribution (i.e. the $10^{\text {th }}$ centile of the poorest respondents in the sample). We report contrasts of predictive margins (the difference in probabilities) for

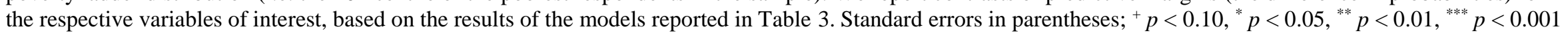


Table 5. Subjective and Objective Poverty Ladder: Regional Differences \& Entrepreneurship-Gender Interaction Effects.

\begin{tabular}{|c|c|c|c|c|c|c|c|c|}
\hline \multirow{2}{*}{$\begin{array}{l}\text { Variables/Model } \\
\text { specification }\end{array}$} & \multicolumn{2}{|c|}{ CEB } & \multicolumn{2}{|c|}{ SEE } & \multicolumn{2}{|c|}{ EEC } & \multicolumn{2}{|c|}{$\mathbf{C A}$} \\
\hline & $\begin{array}{c}\text { Model } 5 \\
\text { Subjective }\end{array}$ & $\begin{array}{c}\text { Model } 6 \\
\text { Objective }\end{array}$ & $\begin{array}{c}\text { Model } 7 \\
\text { Subjective }\end{array}$ & $\begin{array}{c}\text { Model } 8 \\
\text { Objective }\end{array}$ & $\begin{array}{c}\text { Model } 9 \\
\text { Subjective }\end{array}$ & $\begin{array}{l}\text { Model } 10 \\
\text { Objective }\end{array}$ & $\begin{array}{c}\text { Model } 11 \\
\text { Subjective }\end{array}$ & $\begin{array}{l}\text { Model } 12 \\
\text { Objective }\end{array}$ \\
\hline $\begin{array}{l}\text { Subjective poverty ladder } \\
(\mathrm{t}-4)\end{array}$ & $\begin{array}{l}0.601^{* * *} \\
(0.0105)\end{array}$ & $\begin{array}{l}0.0784^{* * * *} \\
(0.00989)\end{array}$ & $\begin{array}{l}0.670^{* * *} \\
(0.0120)\end{array}$ & $\begin{array}{l}0.0882^{\text {*** }} \\
(0.0108)\end{array}$ & $\begin{array}{l}0.451^{* * *} \\
(0.0104)\end{array}$ & $\begin{array}{l}0.0795^{* * *} \\
(0.0101)\end{array}$ & $\begin{array}{l}0.509^{* * *} \\
(0.0173)\end{array}$ & $\begin{array}{l}0.0870^{* * *} \\
(0.0158)\end{array}$ \\
\hline Urban & $\begin{array}{l}-0.00222 \\
(0.0324)\end{array}$ & $\begin{array}{l}-0.0301 \\
(0.0369)\end{array}$ & $\begin{array}{c}-0.0994^{* *} \\
(0.0341)\end{array}$ & $\begin{array}{c}0.0593 \\
(0.0383)\end{array}$ & $\begin{array}{r}-0.00924 \\
(0.0418)\end{array}$ & $\begin{array}{l}0.219^{* * * *} \\
(0.0477)\end{array}$ & $\begin{array}{l}-0.204^{* *} \\
(0.0724)\end{array}$ & $\begin{array}{c}0.105 \\
(0.0710)\end{array}$ \\
\hline Age & $\begin{array}{l}-0.040^{* * *} \\
(0.0089)\end{array}$ & $\begin{array}{l}-0.00645 \\
(0.00993)\end{array}$ & $\begin{array}{l}-0.0277^{* *} \\
(0.00981)\end{array}$ & $\begin{array}{l}-0.0195^{+} \\
(0.0108)\end{array}$ & $\begin{array}{l}-0.0325^{* *} \\
(0.0101)\end{array}$ & $\begin{array}{l}-0.0238^{*} \\
(0.0111)\end{array}$ & $\begin{array}{l}-0.0100 \\
(0.0141)\end{array}$ & $\begin{array}{c}-0.0805^{* * *} \\
(0.0149)\end{array}$ \\
\hline Age squared & $\begin{array}{c}0.0003^{* * *} \\
(0.0001)\end{array}$ & $\begin{array}{c}-0.000105 \\
(0.000116 \\
)\end{array}$ & $\begin{array}{l}0.000267^{*} \\
(0.000116)\end{array}$ & $\begin{array}{c}0.000204 \\
(0.000128)\end{array}$ & $\begin{array}{l}0.000318^{* *} \\
(0.000120)\end{array}$ & $\begin{array}{c}0.000206 \\
(0.000132)\end{array}$ & $\begin{array}{l}0.0000750 \\
(0.000172)\end{array}$ & $\begin{array}{l}0.00102^{* * *} \\
(0.000183)\end{array}$ \\
\hline Married & $\begin{array}{l}0.108^{* * *} \\
(0.0296)\end{array}$ & $\begin{array}{l}0.737^{* * *} \\
(0.0346)\end{array}$ & $\begin{array}{l}0.129^{* * *} \\
(0.0362)\end{array}$ & $\begin{array}{l}0.360^{* * *} \\
(0.0407)\end{array}$ & $\begin{array}{c}0.102^{* *} \\
(0.0373)\end{array}$ & $\begin{array}{l}0.540^{* * * *} \\
(0.0425)\end{array}$ & $\begin{array}{l}0.0958^{+} \\
(0.0557)\end{array}$ & $\begin{array}{l}0.468^{* * * *} \\
(0.0596)\end{array}$ \\
\hline $\begin{array}{l}\text { Gender } \\
(\text { Female=1) }\end{array}$ & $\begin{array}{l}-0.122^{* * *} \\
(0.0297)\end{array}$ & $\begin{array}{l}-0.182^{* * *} \\
(0.0338)\end{array}$ & $\begin{array}{l}-0.0113 \\
(0.0339)\end{array}$ & $\begin{array}{c}0.0361 \\
(0.0377)\end{array}$ & $\begin{array}{l}-0.0342 \\
(0.0369)\end{array}$ & $\begin{array}{l}-0.0425 \\
(0.0416)\end{array}$ & $\begin{array}{c}0.0364 \\
(0.0513)\end{array}$ & $\begin{array}{c}-0.0464 \\
(0.0536)\end{array}$ \\
\hline Higher education & $\begin{array}{l}0.112^{* * *} \\
(0.0108)\end{array}$ & $\begin{array}{l}0.194^{* * *} \\
(0.0127)\end{array}$ & $\begin{array}{l}0.102^{* * *} \\
(0.0122)\end{array}$ & $\begin{array}{l}0.188^{* * * *} \\
(0.0136)\end{array}$ & $\begin{array}{c}0.0332^{*} \\
(0.0131)\end{array}$ & $\begin{array}{l}0.143^{* * *} \\
(0.0146)\end{array}$ & $\begin{array}{l}0.102^{* * * *} \\
(0.0191)\end{array}$ & $\begin{array}{l}0.145^{* * *} \\
(0.0200)\end{array}$ \\
\hline Internet access & $\begin{array}{l}0.295^{* * *} \\
(0.0507)\end{array}$ & $\begin{array}{l}0.745^{* * *} \\
(0.0564)\end{array}$ & $\begin{array}{l}0.300^{* * *} \\
(0.0456)\end{array}$ & $\begin{array}{l}0.649^{* * *} \\
(0.0505)\end{array}$ & $\begin{array}{l}0.199^{* * *} \\
(0.0431)\end{array}$ & $\begin{array}{l}0.589^{* * *} \\
(0.0478)\end{array}$ & $\begin{array}{l}0.454^{* * *} \\
(0.0568)\end{array}$ & $\begin{array}{l}0.528^{* * *} \\
(0.0584)\end{array}$ \\
\hline $\begin{array}{l}\text { Empl_status1 } \\
\text { (unemployed) }\end{array}$ & $\begin{array}{c}-0.764^{* * *} \\
(0.0895)\end{array}$ & $\begin{array}{c}-0.988^{* * *} \\
(0.0962)\end{array}$ & $\begin{array}{c}-0.466^{* * *} \\
(0.0688)\end{array}$ & $\begin{array}{c}-0.669^{* * *} \\
(0.0781)\end{array}$ & $\begin{array}{c}-0.455^{\text {*** }} \\
(0.0736)\end{array}$ & $\begin{array}{c}-0.732^{* * *} \\
(0.0821)\end{array}$ & $\begin{array}{c}-0.342^{* *} \\
(0.113)\end{array}$ & $\begin{array}{c}-0.461^{* * *} \\
(0.122)\end{array}$ \\
\hline
\end{tabular}




Empl_status1\#
Female
Empl_status3
(self-employed)
Empl_status3\#
Female
Empl_status4
(business owner)
Empl_status4\#
Female
Phys_infrast_satisf
Family_Trust
Inst_Trust
Inst_Trust
(NUTS3-country)
Neighbourhost_satisf

\begin{tabular}{|c|c|c|c|}
\hline $0.316^{* *}$ & 0.00354 & 0.0781 & 0.0187 \\
\hline$(0.116)$ & $(0.126)$ & $(0.0979)$ & (0.109) \\
\hline $\begin{array}{c}0.0990 \\
(0.0828)\end{array}$ & $\begin{array}{c}0.0402 \\
(0.0993)\end{array}$ & $\begin{array}{l}-0.0557 \\
(0.0800)\end{array}$ & $\begin{array}{c}-0.0682 \\
(0.0922)\end{array}$ \\
\hline 0.0167 & 0.00352 & 0.0926 & 0.0646 \\
\hline$(0.125)$ & $(0.152)$ & $(0.132)$ & $(0.148)$ \\
\hline $\begin{array}{l}0.280^{* *} \\
(0.101)\end{array}$ & $\begin{array}{c}0.499^{* * *} \\
(0.128)\end{array}$ & $\begin{array}{l}0.359^{* *} \\
(0.110)\end{array}$ & $\begin{array}{c}0.740^{* * *} \\
(0.133)\end{array}$ \\
\hline 0.191 & 0.357 & -0.0404 & 0.0570 \\
\hline$(0.173)$ & $(0.237)$ & $(0.197)$ & $(0.248)$ \\
\hline $\begin{array}{c}0.0819^{* * *} \\
(0.0220)\end{array}$ & $\begin{array}{l}0.122^{* * *} \\
(0.0252)\end{array}$ & $\begin{array}{l}0.124^{* * *} \\
(0.0186)\end{array}$ & $\begin{array}{c}0.0249 \\
(0.0206)\end{array}$ \\
\hline $0.132^{+}$ & 0.0657 & 0.0493 & -0.00436 \\
\hline$(0.0705)$ & $(0.0914)$ & $(0.0473)$ & $(0.0662)$ \\
\hline $\begin{array}{l}0.255^{\text {*** }} \\
(0.0239)\end{array}$ & $\begin{array}{c}0.0975^{\text {*** }} \\
(0.0271)\end{array}$ & $\begin{array}{l}0.197^{* * *} \\
(0.0220)\end{array}$ & $\begin{array}{l}0.0715^{* *} \\
(0.0247)\end{array}$ \\
\hline $\begin{array}{c}0.108 \\
(0.0898)\end{array}$ & $\begin{array}{l}0.210^{+} \\
(0.123)\end{array}$ & $\begin{array}{c}0.0137 \\
(0.0609)\end{array}$ & $\begin{array}{c}0.0103 \\
(0.0806)\end{array}$ \\
\hline $\begin{array}{c}0.0875 \\
(0.0803)\end{array}$ & $\begin{array}{c}0.301^{* *} \\
(0.0930)\end{array}$ & $\begin{array}{c}0.0750 \\
(0.0898)\end{array}$ & $\begin{array}{c}0.249^{*} \\
(0.101)\end{array}$ \\
\hline 0.0369 & 0.0221 & 0.0491 & 0.0332 \\
\hline
\end{tabular}

$0.259^{*}$
$(0.104)$
-0.0925
$(0.105)$
0.0559
$(0.155)$
$0.289^{+}$
$(0.164)$
0.242
$(0.296)$
$0.121^{* * *}$
$(0.0229)$
-0.0222
$(0.0604)$
$0.131^{* * *}$
$(0.0249)$
0.0344
$(0.0631)$
-0.0945
$(0.0740)$
0.0366

0.156
$(0.114)$
0.0838
$(0.121)$
-0.284
$(0.181)$

$0.425^{*}$
$(0.206)$

0.324
$(0.352)$
$0.0427^{+}$
$(0.0253)$
0.0835
$(0.0628)$
-0.00700
$(0.0280)$
-0.0609
$(0.0670)$
$0.216^{*}$
$(0.0865)$

$0.396^{*}$

$-0.0253$

(0.174)

(0.185)

$-0.0557$

$-0.0682$

(0.0800)

(0.0922)

0.0926

0.0646

(0.132)

(0.148)

$0.359^{* *}$

$0.740^{* * * *}$

(0.110)

(0.133)

$-0.0404$

0.0570

(0.197)

(0.248)

$0.0636^{*}$

0.0356

(0.0280)

(0.0291)

0.00937

0.0446

(0.0391)

(0.0358)

$0.124^{* *}$

$-0.0202$

(0.0394)

(0.0423)

$-0.0710$

$-0.115^{+}$

(0.0692)

(0.0614)

0.187
$(0.150)$
$0.141^{*}$

$0.427^{*}$

(0.166)

0.0643 


\begin{tabular}{|c|c|c|c|c|c|c|c|c|}
\hline & $(0.0321)$ & $(0.0366)$ & $(0.0348)$ & $(0.0391)$ & $(0.0360)$ & $(0.0410)$ & $(0.0604)$ & $(0.0642)$ \\
\hline $\begin{array}{l}\text { Family_Trust } \\
\text { (NUTS3-country) }\end{array}$ & $\begin{array}{l}0.0995 \\
(0.594)\end{array}$ & $\begin{array}{c}1.769^{*} \\
(0.837)\end{array}$ & $\begin{array}{l}-1.103 \\
(0.730)\end{array}$ & $\begin{array}{c}1.245 \\
(0.977)\end{array}$ & $\begin{array}{l}-0.329 \\
(0.507)\end{array}$ & $\begin{array}{l}-0.623 \\
(0.521)\end{array}$ & $\begin{array}{l}2.400^{+} \\
(1.284)\end{array}$ & $\begin{array}{l}-1.395 \\
(1.125)\end{array}$ \\
\hline $\begin{array}{l}\text { Neighbourhood_Trust } \\
\text { (NUTS3-country) }\end{array}$ & $\begin{array}{l}-0.189 \\
(0.289)\end{array}$ & $\begin{array}{l}-0.846^{+} \\
(0.434)\end{array}$ & $\begin{array}{l}-0.127 \\
(0.261)\end{array}$ & $\begin{array}{l}-0.0785 \\
(0.369)\end{array}$ & $\begin{array}{l}-0.286 \\
(0.296)\end{array}$ & $\begin{array}{l}-0.115 \\
(0.316)\end{array}$ & $\begin{array}{l}-0.484 \\
(0.357)\end{array}$ & $\begin{array}{c}0.141 \\
(0.327)\end{array}$ \\
\hline $\begin{array}{l}\text { Informal_contract } \\
\text { (NUTS3-country) }\end{array}$ & $\begin{array}{l}-0.626 \\
(0.524)\end{array}$ & $\begin{array}{l}-0.162 \\
(0.718)\end{array}$ & $\begin{array}{l}-0.500^{+} \\
(0.295)\end{array}$ & $\begin{array}{l}-0.144 \\
(0.406)\end{array}$ & $\begin{array}{l}-0.272 \\
(0.226)\end{array}$ & $\begin{array}{l}-0.631^{* *} \\
(0.235)\end{array}$ & $\begin{array}{l}-0.625^{* *} \\
(0.203)\end{array}$ & $\begin{array}{l}-0.155 \\
(0.182)\end{array}$ \\
\hline $\begin{array}{l}\text { Institutional_quality } \\
\text { (country-level) }\end{array}$ & $\begin{array}{l}-0.0611 \\
(0.249)\end{array}$ & $\begin{array}{l}-0.0770 \\
(0.247)\end{array}$ & $\begin{array}{l}-0.331 \\
(0.319)\end{array}$ & $\begin{array}{l}-0.381 \\
(0.359)\end{array}$ & $\begin{array}{r}-0.0372 \\
(0.154)\end{array}$ & $\begin{array}{c}0.332^{*} \\
(0.158)\end{array}$ & $\begin{array}{l}-0.588 \\
(0.777)\end{array}$ & $\begin{array}{l}-0.821 \\
(0.688)\end{array}$ \\
\hline $\begin{array}{l}\text { GDP growth } \\
\text { (country-level) }\end{array}$ & $\begin{array}{c}0.102^{+} \\
(0.0529)\end{array}$ & $\begin{array}{l}-0.0544 \\
(0.0512)\end{array}$ & $\begin{array}{c}0.0622 \\
(0.0646)\end{array}$ & $\begin{array}{l}-0.0474 \\
(0.0692)\end{array}$ & $\begin{array}{c}0.0297^{*} \\
(0.0147)\end{array}$ & $\begin{array}{l}-0.0112 \\
(0.0153)\end{array}$ & $\begin{array}{c}0.0356 \\
(0.0563)\end{array}$ & $\begin{array}{c}0.0116 \\
(0.0494)\end{array}$ \\
\hline GDPpc (iq2) & $\begin{array}{l}0 \\
(.)\end{array}$ & $\begin{array}{c}0 \\
(.)\end{array}$ & $\begin{array}{c}-0.0392 \\
(0.203)\end{array}$ & $\begin{array}{c}0.243 \\
(0.233)\end{array}$ & $\begin{array}{c}-0.336^{+} \\
(0.178)\end{array}$ & $\begin{array}{l}-0.288 \\
(0.184)\end{array}$ & $\begin{array}{c}0 \\
\text { (.) }\end{array}$ & $\begin{array}{c}0 \\
(.)\end{array}$ \\
\hline GDPpc (iq3) & $\begin{array}{l}0 \\
(.)\end{array}$ & $\begin{array}{l}0 \\
(.)\end{array}$ & $\begin{array}{l}-0.122 \\
(0.312)\end{array}$ & $\begin{array}{c}0.583 \\
(0.365)\end{array}$ & $\begin{array}{l}-0.147 \\
(0.120)\end{array}$ & $\begin{array}{l}-0.281^{*} \\
(0.125)\end{array}$ & $\begin{array}{r}-0.0172 \\
(0.609)\end{array}$ & $\begin{array}{c}0.416 \\
(0.539)\end{array}$ \\
\hline $\begin{array}{l}\text { GDPpc (iq4) } \\
\text { GDPpc (iq5) }\end{array}$ & $\begin{array}{c}0.00864 \\
(0.148) \\
0 \\
(.)\end{array}$ & $\begin{array}{c}-0.353^{*} \\
(0.144) \\
0 \\
(.)\end{array}$ & $\begin{array}{c}0 \\
(.) \\
0 \\
(.)\end{array}$ & $\begin{array}{c}0 \\
(.) \\
0 \\
(.)\end{array}$ & $\begin{array}{c}0 \\
(.) \\
0 \\
(.)\end{array}$ & $\begin{array}{c}0 \\
(.) \\
0 \\
(.)\end{array}$ & $\begin{array}{c}0 \\
(.) \\
0 \\
(.)\end{array}$ & $\begin{array}{c}0 \\
(.) \\
0 \\
(.)\end{array}$ \\
\hline $\begin{array}{l}\text { var(CountryTE) } \\
\text { _cont }\end{array}$ & $\begin{array}{c}0.0167 \\
(0.0107)\end{array}$ & $\begin{array}{l}0.00795 \\
(0.0128)\end{array}$ & $\begin{array}{c}0.00738 \\
(0.00733)\end{array}$ & $\begin{array}{c}3.93 e-34 \\
(4.53 e-18)\end{array}$ & $\begin{array}{c}2.82 \mathrm{e}-32 \\
(1.02 \mathrm{e}-17)\end{array}$ & $\begin{array}{c}4.20 \mathrm{e}-37 \\
(1.43 \mathrm{e}-20)\end{array}$ & $\begin{array}{c}4.01 \mathrm{e}-37 \\
(8.38 \mathrm{e}-21)\end{array}$ & $\begin{array}{c}9.33 \mathrm{e}-39 \\
(5.13 \mathrm{e}-22)\end{array}$ \\
\hline $\begin{array}{l}\text { var(NUTS3_CountryTE) } \\
\text { _cont }\end{array}$ & $\begin{array}{c}0.0573^{* * *} \\
(0.0143)\end{array}$ & $\begin{array}{l}0.120^{* * *} \\
(0.0245)\end{array}$ & $\begin{array}{c}0.0645^{* * *} \\
(0.0151)\end{array}$ & $\begin{array}{l}0.160^{* * *} \\
(0.0286)\end{array}$ & $\begin{array}{l}0.141^{* * *} \\
(0.0222)\end{array}$ & $\begin{array}{l}0.141^{* * *} \\
(0.0237)\end{array}$ & $\begin{array}{l}0.211^{* * *} \\
(0.0364)\end{array}$ & $\begin{array}{l}0.128^{* * *} \\
(0.0269)\end{array}$ \\
\hline$N$ & 6066 & 4595 & 5063 & 3958 & 4458 & 3496 & 2396 & 2054 \\
\hline
\end{tabular}

Standard errors in parentheses $;{ }^{+} p<0.10,{ }^{*} p<0.05,{ }^{* *} p<0.01,{ }^{* * *} p<0.001$.

Note: CEB- Central Europe and Baltic states; SEE -South East Europe; ECC - Eastern Europe; CA - Central Asia. 
Table 6. Subjective and Objective Poverty Occurrence: Regional Differences \& Gender-Employment Status Interaction Effects (poverty measures reflect the bottom quintile of the self-perceived and reported poverty income ladder distribution)

\begin{tabular}{|c|c|c|c|c|c|c|c|c|}
\hline \multirow{3}{*}{ Variables/model specification } & \multicolumn{2}{|c|}{ CEB } & \multicolumn{2}{|c|}{ SEE } & \multicolumn{2}{|c|}{ EEC } & \multicolumn{2}{|c|}{$\mathbf{C A}$} \\
\hline & Model 13 & Model 14 & Model 15 & Model 16 & Model 17 & Model 18 & Model 19 & Model 20 \\
\hline & $\begin{array}{c}\text { Subjective } \\
\text { Poverty20th } \\
\text { centile }\end{array}$ & $\begin{array}{c}\text { Objective } \\
\text { Poverty20th } \\
\text { centile }\end{array}$ & $\begin{array}{c}\text { Subjective } \\
\text { Poverty } 20 t \\
\text { h centile } \\
\end{array}$ & $\begin{array}{c}\text { Objective } \\
\text { Poverty } 20 t \\
\text { h centile } \\
\end{array}$ & $\begin{array}{c}\text { Subjective } \\
\text { Poverty20th } \\
\text { centile } \\
\end{array}$ & $\begin{array}{c}\text { Objective } \\
\text { Poverty20th } \\
\text { centile }\end{array}$ & $\begin{array}{c}\text { Subjective } \\
\text { Poverty20th } \\
\text { centile }\end{array}$ & $\begin{array}{c}\text { Objective } \\
\text { Poverty20th } \\
\text { centile }\end{array}$ \\
\hline $\begin{array}{l}\text { Subjective } \\
\text { poverty20th centile }(\mathrm{t}-4)\end{array}$ & $\begin{array}{l}2.077^{* * *} \\
(0.0826)\end{array}$ & $\begin{array}{c}0.385^{* * *} \\
(0.108)\end{array}$ & $\begin{array}{l}2.146^{* * *} \\
(0.0919)\end{array}$ & $\begin{array}{c}0.487^{* * *} \\
(0.104)\end{array}$ & $\begin{array}{l}1.783^{* * *} \\
(0.0786)\end{array}$ & $\begin{array}{l}0.377^{* * *} \\
(0.0952)\end{array}$ & $\begin{array}{c}1.846^{* * * *} \\
(0.135)\end{array}$ & $\begin{array}{c}0.340^{* * *} \\
(0.107)\end{array}$ \\
\hline Urban & $\begin{array}{c}0.0384 \\
(0.0756)\end{array}$ & $\begin{array}{l}-0.0519 \\
(0.0784)\end{array}$ & $\begin{array}{c}0.137 \\
(0.0858)\end{array}$ & $\begin{array}{c}0.0697 \\
(0.0724)\end{array}$ & $\begin{array}{l}-0.0755 \\
(0.0731)\end{array}$ & $\begin{array}{l}-0.150^{+} \\
(0.0800)\end{array}$ & $\begin{array}{l}0.304^{+} \\
(0.161)\end{array}$ & $\begin{array}{l}-0.151 \\
(0.102)\end{array}$ \\
\hline Age & $\begin{array}{l}0.0750^{* *} \\
(0.0238)\end{array}$ & $\begin{array}{c}0.0101 \\
(0.0219)\end{array}$ & $\begin{array}{c}0.0283 \\
(0.0239)\end{array}$ & $\begin{array}{l}-0.0215 \\
(0.0197)\end{array}$ & $\begin{array}{l}0.0502^{*} \\
(0.0201)\end{array}$ & $\begin{array}{l}0.0426^{*} \\
(0.0212)\end{array}$ & $\begin{array}{c}0.0279 \\
(0.0378)\end{array}$ & $\begin{array}{l}0.100^{* * *} \\
(0.0249)\end{array}$ \\
\hline Age squared & $\begin{array}{c}-0.000762^{* *} \\
(0.000273)\end{array}$ & $\begin{array}{l}0.0000434 \\
(0.000253)\end{array}$ & $\begin{array}{l}-0.000266 \\
(0.000280)\end{array}$ & $\begin{array}{c}0.000265 \\
(0.000233)\end{array}$ & $\begin{array}{l}-0.000489^{*} \\
(0.000234)\end{array}$ & $\begin{array}{l}-0.000400 \\
(0.000248)\end{array}$ & $\begin{array}{l}-0.000126 \\
(0.000452)\end{array}$ & $\begin{array}{l}-0.00125^{* * * *} \\
(0.000307)\end{array}$ \\
\hline Married & $\begin{array}{l}-0.127^{+} \\
(0.0734)\end{array}$ & $\begin{array}{l}-0.799^{* * *} \\
(0.0852)\end{array}$ & $\begin{array}{c}-0.166^{+} \\
(0.0893)\end{array}$ & $\begin{array}{l}-0.240^{* *} \\
(0.0780)\end{array}$ & $\begin{array}{l}-0.285^{* * * *} \\
(0.0689)\end{array}$ & $\begin{array}{l}-0.517^{* * * *} \\
(0.0786)\end{array}$ & $\begin{array}{l}-0.205 \\
(0.135)\end{array}$ & $\begin{array}{l}-0.440^{* * *} \\
(0.0947)\end{array}$ \\
\hline Gender & $\begin{array}{l}-0.0494 \\
(0.0798)\end{array}$ & $\begin{array}{c}0.204^{*} \\
(0.0869)\end{array}$ & $\begin{array}{l}-0.0167 \\
(0.0925)\end{array}$ & $\begin{array}{c}0.0897 \\
(0.0783)\end{array}$ & $\begin{array}{c}0.107 \\
(0.0735)\end{array}$ & $\begin{array}{c}0.0436 \\
(0.0866)\end{array}$ & $\begin{array}{l}-0.0355 \\
(0.133)\end{array}$ & $\begin{array}{l}-0.0170 \\
(0.0888)\end{array}$ \\
\hline Higher education & $\begin{array}{l}-0.137^{* * *} \\
(0.0294)\end{array}$ & $\begin{array}{l}-0.184^{* * *} \\
(0.0328)\end{array}$ & $\begin{array}{l}-0.133^{* * * *} \\
(0.0324)\end{array}$ & $\begin{array}{l}-0.150^{* * * *} \\
(0.0266)\end{array}$ & $\begin{array}{c}-0.0745^{* *} \\
(0.0247)\end{array}$ & $\begin{array}{l}-0.118^{* * *} \\
(0.0276)\end{array}$ & $\begin{array}{l}-0.165^{* *} \\
(0.0514)\end{array}$ & $\begin{array}{l}-0.200^{* * * *} \\
(0.0331)\end{array}$ \\
\hline Internet access & $\begin{array}{l}-0.403^{* * *} \\
(0.0991)\end{array}$ & $\begin{array}{l}-0.693^{* * *} \\
(0.0901)\end{array}$ & $\begin{array}{l}-0.606^{* * *} \\
(0.0911)\end{array}$ & $\begin{array}{l}-0.559^{* * *} \\
(0.0787)\end{array}$ & $\begin{array}{l}-0.331^{* * * *} \\
(0.0727)\end{array}$ & $\begin{array}{l}-0.498^{* * *} \\
(0.0783)\end{array}$ & $\begin{array}{c}-0.646^{* * *} \\
(0.147)\end{array}$ & $\begin{array}{l}-0.588^{* * *} \\
(0.0937)\end{array}$ \\
\hline Empl_status1 & $0.903^{* * *}$ & $1.266^{* * *}$ & $0.348^{* *}$ & $0.856^{* * *}$ & $0.604^{* * *}$ & $0.708^{* * *}$ & $0.453^{+}$ & $0.682^{* * *}$ \\
\hline
\end{tabular}




\begin{tabular}{|c|c|c|c|c|c|c|c|c|}
\hline (unemployed) & $(0.142)$ & $(0.144)$ & $(0.133)$ & $(0.110)$ & $(0.116)$ & $(0.127)$ & $(0.246)$ & $(0.163)$ \\
\hline \multirow{2}{*}{$\begin{array}{l}\text { Empl_status1\# } \\
\text { Female }\end{array}$} & -0.0862 & -0.214 & -0.122 & -0.219 & -0.186 & -0.161 & -0.665 & -0.00991 \\
\hline & $(0.190)$ & $(0.188)$ & $(0.199)$ & $(0.161)$ & $(0.164)$ & $(0.178)$ & $(0.430)$ & $(0.247)$ \\
\hline $\begin{array}{l}\text { Empl_status3 } \\
\text { (self-employed) }\end{array}$ & $\begin{array}{l}-0.803^{*} \\
(0.363)\end{array}$ & $\begin{array}{l}0.0452 \\
(0.259)\end{array}$ & $\begin{array}{l}-0.0486 \\
(0.204)\end{array}$ & $\begin{array}{c}0.213 \\
(0.168)\end{array}$ & $\begin{array}{c}0.270 \\
(0.188)\end{array}$ & $\begin{array}{c}0.245 \\
(0.221)\end{array}$ & $\begin{array}{l}-0.0873 \\
(0.294)\end{array}$ & $\begin{array}{l}0.0199 \\
(0.181)\end{array}$ \\
\hline \multirow{2}{*}{$\begin{array}{l}\text { Empl_status3\# } \\
\text { Female }\end{array}$} & $1.132^{* *}$ & -0.141 & 0.252 & -0.227 & -0.351 & 0.462 & -0.0581 & $-0.694^{+}$ \\
\hline & $(0.420)$ & $(0.376)$ & $(0.323)$ & $(0.279)$ & $(0.279)$ & $(0.299)$ & $(0.514)$ & $(0.387)$ \\
\hline Empl_status4 & $\begin{array}{l}0.0305 \\
(0.286)\end{array}$ & $\begin{array}{l}-0.250 \\
(0.488)\end{array}$ & $\begin{array}{l}-0.294 \\
(0.618)\end{array}$ & $\begin{array}{l}0 \\
(.)\end{array}$ & $\begin{array}{l}-0.350 \\
(0.460)\end{array}$ & $\begin{array}{c}0.426 \\
(0.362)\end{array}$ & $\begin{array}{l}0.0104 \\
(0.636)\end{array}$ & $\begin{array}{l}-0.398 \\
(0.376)\end{array}$ \\
\hline \multirow{2}{*}{$\begin{array}{l}\text { Empl_status4\# } \\
\text { Female }\end{array}$} & 0.174 & 0.403 & 0 & 0 & 0 & 0 & 0 & -0.218 \\
\hline & $(0.480)$ & $(0.685)$ & (.) & (.) & (.) & (.) & (.) & $(0.740)$ \\
\hline Phys_infrast_satisf & $\begin{array}{l}-0.108^{*} \\
(0.0518)\end{array}$ & $\begin{array}{l}-0.0959^{+} \\
(0.0550)\end{array}$ & $\begin{array}{l}-0.145^{* * *} \\
(0.0416)\end{array}$ & $\begin{array}{l}-0.0167 \\
(0.0383)\end{array}$ & $\begin{array}{l}-0.156^{* * * *} \\
(0.0384)\end{array}$ & $\begin{array}{l}-0.103^{*} \\
(0.0445)\end{array}$ & $\begin{array}{l}-0.0882 \\
(0.0700)\end{array}$ & $\begin{array}{l}-0.0131 \\
(0.0455)\end{array}$ \\
\hline \multirow{2}{*}{$\begin{array}{l}\text { Phys_infrast_satisf (NUTS3- } \\
\text { country) }\end{array}$} & -0.174 & 0.0657 & 0.0228 & 0.0404 & -0.107 & -0.0865 & 0.0608 & -0.0362 \\
\hline & $(0.119)$ & $(0.114)$ & $(0.0677)$ & $(0.0895)$ & $(0.0906)$ & $(0.0930)$ & $(0.0825)$ & $(0.0467)$ \\
\hline Inst_Trust & $\begin{array}{l}-0.267^{* * *} \\
(0.0568)\end{array}$ & $\begin{array}{l}-0.0458 \\
(0.0632)\end{array}$ & $\begin{array}{l}-0.286^{* * *} \\
(0.0584)\end{array}$ & $\begin{array}{l}-0.124^{* *} \\
(0.0465)\end{array}$ & $\begin{array}{l}-0.153^{* *} \\
(0.0476)\end{array}$ & $\begin{array}{l}0.00215 \\
(0.0525)\end{array}$ & $\begin{array}{l}-0.216^{*} \\
(0.0954)\end{array}$ & $\begin{array}{l}-0.0317 \\
(0.0704)\end{array}$ \\
\hline $\begin{array}{l}\text { Inst_Trust } \\
\text { (NUTS3-country) }\end{array}$ & $\begin{array}{l}-0.145 \\
(0.150)\end{array}$ & $\begin{array}{l}-0.132 \\
(0.145)\end{array}$ & $\begin{array}{l}-0.0616 \\
(0.0911)\end{array}$ & $\begin{array}{l}0.0770 \\
(0.115)\end{array}$ & $\begin{array}{c}0.0889 \\
(0.0924)\end{array}$ & $\begin{array}{c}0.0492 \\
(0.0963)\end{array}$ & $\begin{array}{c}-0.0996 \\
(0.136)\end{array}$ & $\begin{array}{c}0.141^{+} \\
(0.0818)\end{array}$ \\
\hline Family_Trust & $\begin{array}{c}-0.0166 \\
(0.179)\end{array}$ & $\begin{array}{l}-0.382^{*} \\
(0.163)\end{array}$ & $\begin{array}{c}0.103 \\
(0.227)\end{array}$ & $\begin{array}{l}-0.363^{*} \\
(0.174)\end{array}$ & $\begin{array}{c}0.180 \\
(0.146)\end{array}$ & $\begin{array}{l}-0.207 \\
(0.152)\end{array}$ & $\begin{array}{l}-0.569^{+} \\
(0.295)\end{array}$ & $\begin{array}{l}-0.592^{*} \\
(0.249)\end{array}$ \\
\hline
\end{tabular}




\begin{tabular}{|c|c|c|c|c|c|c|c|c|}
\hline Neighbourhood_Trust & $\begin{array}{c}0.0177 \\
(0.0774)\end{array}$ & $\begin{array}{c}0.0320 \\
(0.0834)\end{array}$ & $\begin{array}{l}-0.144^{+} \\
(0.0869)\end{array}$ & $\begin{array}{l}-0.0581 \\
(0.0742)\end{array}$ & $\begin{array}{c}-0.110 \\
(0.0691)\end{array}$ & $\begin{array}{c}0.0486 \\
(0.0800)\end{array}$ & $\begin{array}{l}-0.190 \\
(0.145)\end{array}$ & $\begin{array}{l}0.0523 \\
(0.107)\end{array}$ \\
\hline $\begin{array}{l}\text { Family_Trust } \\
\text { (NUTS3-country) }\end{array}$ & $\begin{array}{l}-0.569 \\
(1.127)\end{array}$ & $\begin{array}{l}-0.624 \\
(1.146)\end{array}$ & $\begin{array}{c}1.117 \\
(1.332)\end{array}$ & $\begin{array}{l}-2.917^{*} \\
(1.349)\end{array}$ & $\begin{array}{l}-0.375 \\
(0.821)\end{array}$ & $\begin{array}{c}0.407 \\
(0.865)\end{array}$ & $\begin{array}{l}-6.319^{* *} \\
(2.109)\end{array}$ & $\begin{array}{c}1.193 \\
(1.461)\end{array}$ \\
\hline $\begin{array}{l}\text { Neighbourhood_Trust } \\
\text { (NUTS3-country) }\end{array}$ & $\begin{array}{c}0.528 \\
(0.549)\end{array}$ & $\begin{array}{c}0.857 \\
(0.601)\end{array}$ & $\begin{array}{c}0.249 \\
(0.444)\end{array}$ & $\begin{array}{c}0.311 \\
(0.573)\end{array}$ & $\begin{array}{c}0.646 \\
(0.447)\end{array}$ & $\begin{array}{c}0.467 \\
(0.494)\end{array}$ & $\begin{array}{l}1.974^{* *} \\
(0.743)\end{array}$ & $\begin{array}{l}-0.417 \\
(0.425)\end{array}$ \\
\hline $\begin{array}{l}\text { Informal_contract } \\
\text { (NUTS3-country) }\end{array}$ & $\begin{array}{l}-0.296 \\
(0.871)\end{array}$ & $\begin{array}{c}1.320 \\
(0.830)\end{array}$ & $\begin{array}{l}1.065^{*} \\
(0.426)\end{array}$ & $\begin{array}{l}-0.163 \\
(0.548)\end{array}$ & $\begin{array}{l}-0.211 \\
(0.324)\end{array}$ & $\begin{array}{l}1.116^{* * * *} \\
(0.320)\end{array}$ & $\begin{array}{l}1.158^{* *} \\
(0.368)\end{array}$ & $\begin{array}{c}0.125 \\
(0.235)\end{array}$ \\
\hline $\begin{array}{l}\text { Institutional_quality } \\
\text { (country-level) }\end{array}$ & $\begin{array}{c}0.186 \\
(0.238)\end{array}$ & $\begin{array}{l}-0.118 \\
(0.242)\end{array}$ & $\begin{array}{c}0.172 \\
(0.392)\end{array}$ & $\begin{array}{c}0.204 \\
(0.483)\end{array}$ & $\begin{array}{l}-0.192 \\
(0.189)\end{array}$ & $\begin{array}{l}-0.353^{+} \\
(0.193)\end{array}$ & $\begin{array}{l}4.676^{*} \\
(1.898)\end{array}$ & $\begin{array}{c}1.075 \\
(0.927)\end{array}$ \\
\hline $\begin{array}{l}\text { GDP growth } \\
\text { (country-level) }\end{array}$ & $\begin{array}{c}-0.0652 \\
(0.0472)\end{array}$ & $\begin{array}{c}0.0908^{+} \\
(0.0484)\end{array}$ & $\begin{array}{c}-0.105 \\
(0.0743)\end{array}$ & $\begin{array}{c}0.163^{+} \\
(0.0934)\end{array}$ & $\begin{array}{l}-0.00140 \\
(0.0190)\end{array}$ & $\begin{array}{c}0.0425^{*} \\
(0.0208)\end{array}$ & $\begin{array}{l}0.394^{* *} \\
(0.130)\end{array}$ & $\begin{array}{c}0.0865 \\
(0.0625)\end{array}$ \\
\hline GDPpc (iq2) & $\begin{array}{l}0 \\
(.)\end{array}$ & $\begin{array}{l}0 \\
(.)\end{array}$ & $\begin{array}{c}0.00323 \\
(0.238)\end{array}$ & $\begin{array}{l}-0.0637 \\
(0.299)\end{array}$ & $\begin{array}{c}0.212 \\
(0.229)\end{array}$ & $\begin{array}{c}0.334 \\
(0.229)\end{array}$ & $\begin{array}{c}0 \\
(.)\end{array}$ & $\begin{array}{l}0 \\
(.)\end{array}$ \\
\hline GDPpc (iq3) & $\begin{array}{l}0 \\
(.)\end{array}$ & $\begin{array}{l}0 \\
(.)\end{array}$ & $\begin{array}{c}0.409 \\
(0.361)\end{array}$ & $\begin{array}{l}-0.565 \\
(0.470)\end{array}$ & $\begin{array}{l}0.0450 \\
(0.166)\end{array}$ & $\begin{array}{c}0.179 \\
(0.169)\end{array}$ & $\begin{array}{l}-1.785 \\
(1.348)\end{array}$ & $\begin{array}{l}-0.169 \\
(0.739)\end{array}$ \\
\hline GDPpc (iq4) & $\begin{array}{c}0.132 \\
(0.138)\end{array}$ & $\begin{array}{l}0.0586 \\
(0.139)\end{array}$ & $\begin{array}{l}0 \\
(.)\end{array}$ & $\begin{array}{l}0 \\
(.)\end{array}$ & $\begin{array}{l}0 \\
(.)\end{array}$ & $\begin{array}{l}0 \\
(.)\end{array}$ & $\begin{array}{l}0 \\
(.)\end{array}$ & $\begin{array}{l}0 \\
(.)\end{array}$ \\
\hline $\begin{array}{l}\text { GDPpc (iq5) } \\
\text { _cons }\end{array}$ & $\begin{array}{c}0 \\
(.) \\
-2.669^{*} \\
(1.192)\end{array}$ & $\begin{array}{c}0 \\
(.) \\
-0.691 \\
(1.212)\end{array}$ & $\begin{array}{c}0 \\
(.) \\
-3.077^{*} \\
(1.401)\end{array}$ & $\begin{array}{c}0 \\
(.) \\
2.632^{+} \\
(1.368)\end{array}$ & $\begin{array}{c}0 \\
(.) \\
-2.469^{* *} \\
(0.891)\end{array}$ & $\begin{array}{c}0 \\
(.) \\
-2.401^{* *} \\
(0.920)\end{array}$ & $\begin{array}{c}0 \\
(.) \\
8.144^{*} \\
(3.288)\end{array}$ & $\begin{array}{c}0 \\
(.) \\
-0.813 \\
(1.932)\end{array}$ \\
\hline $\begin{array}{l}\text { Var(countryTE) } \\
\text { cons }\end{array}$ & $\begin{array}{c}4.48 \mathrm{e}-35 \\
(4.39 \mathrm{e}-19)\end{array}$ & $\begin{array}{c}4.40 \mathrm{e}-38 \\
(9.64 \mathrm{e}-21)\end{array}$ & $\begin{array}{c}3.52 \mathrm{e}-35 \\
(3.93 \mathrm{e}-19)\end{array}$ & $\begin{array}{c}1.16 \mathrm{e}-32 \\
(1.43 \mathrm{e}-17)\end{array}$ & $\begin{array}{c}4.91 \mathrm{e}-35 \\
(3.35 \mathrm{e}-19)\end{array}$ & $\begin{array}{c}3.64 \mathrm{e}-36 \\
(1.30 \mathrm{e}-19)\end{array}$ & $\begin{array}{c}1.16 \mathrm{e}-34 \\
(2.49 \mathrm{e}-17)\end{array}$ & $\begin{array}{l}2.10 \mathrm{e}-35 \\
(3.42 \mathrm{e}-19)\end{array}$ \\
\hline $\begin{array}{l}\overline{\text { Var(NUTS3_CountryTE) }} \\
\bar{N} \text { cons }\end{array}$ & $\begin{array}{c}0.0451^{+} \\
(0.0270) \\
6066\end{array}$ & $\begin{array}{c}0.0334 \\
(0.0282) \\
4595\end{array}$ & $\begin{array}{c}0.0398 \\
(0.0296) \\
4965\end{array}$ & $\begin{array}{c}0.191^{* * *} \\
(0.0461) \\
3861\end{array}$ & $\begin{array}{c}0.142^{* * *} \\
(0.0376) \\
4440\end{array}$ & $\begin{array}{c}0.123^{* *} \\
(0.0435) \\
3481\end{array}$ & $\begin{array}{c}0.253^{*} \\
(0.120) \\
2358\end{array}$ & $\begin{array}{c}0.116^{* *} \\
(0.0414) \\
2054\end{array}$ \\
\hline
\end{tabular}

Standard errors in parentheses; ${ }^{+} p<0.10,{ }^{*} p<0.05,{ }^{* *} p<0.01,{ }^{* * *} p<0.001$

Note: CEB- Central Europe and Baltic states; SEE -South East Europe; ECC - Eastern Europe; CA - Central Asia. 